\title{
Are Court Orders Responsible for the "Return to the Central City"?: The Consequence of School Finance Litigation
}

\author{
Zachary Liscow ${ }^{1}$ \\ Yale Law School \\ December 2013
}

\begin{abstract}
City living in the United States often requires paying high taxes and receiving low-quality services, partly as a result of the large number of poor residents in cities. This is the first paper to measure how much this feature of American local government affects individuals' residential location choices. I do this by taking advantage of a natural experiment: the dramatic increase in state financing of local governments in some states' poor cities, often due to court-ordered school finance equalization. I use the universe of over 20,000 Census-designated places to compare population growth of cities between states with large amount of redistribution to poor cities and states with little redistribution. The key threats to accurate measurement are that poor places may have grown differently from rich places in the absence of redistribution, and places in high-redistribution states may have grown differently from places in low-redistribution states. To address these concerns, I use the "differences-in-differences" econometric technique. The results show that redistribution had a large effect on population growth between 1980 and 2010, helping explain the "return to the city" in recent decades. I then do a case study on the local finances of Connecticut, which shows that the state transfers for education were used not only to increase education spending as intended, but also reduce tax rates. Since this paper shows that redistribution to poor areas mitigates the distortion to individuals' location choices resulting from poor cities' high tax rates and poor services, it suggests that further place-based redistribution may be not only equitable but also efficient.
\end{abstract}

\footnotetext{
${ }^{1}$ Thanks to Ian Ayres, Robert Ellickson, Peter Ganong, Jonah Gelbach, Rick Hills, Christine Jolls, Jon Klick, David Liscow, Yair Listokin, Manisha Padi, Carol Rose, William Woolston, and participants at the Conference on Empirical Legal Studies for helpful comments. All errors are my own.
} 


\section{Contents}

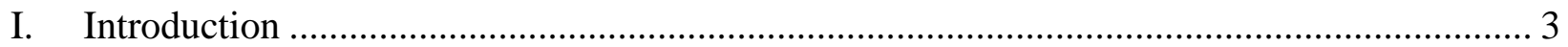

II. Contribution to How Cities Work and How City Government Should Be Structured......... 8

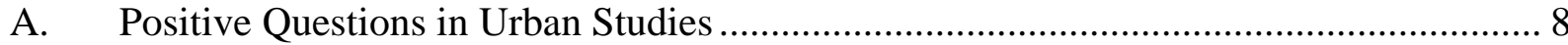

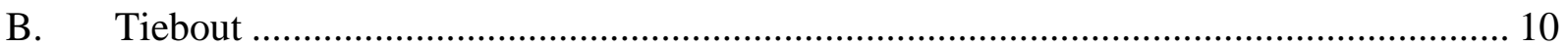

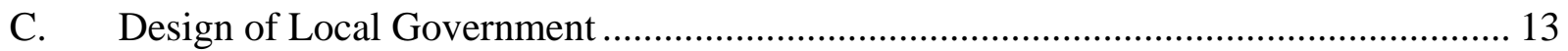

D. Design of Local Government Finances .......................................................................... 14

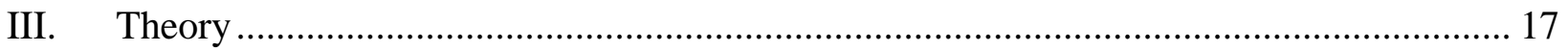

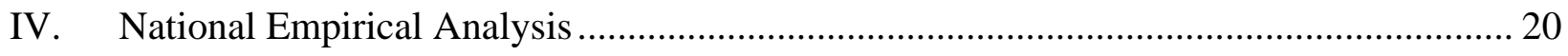

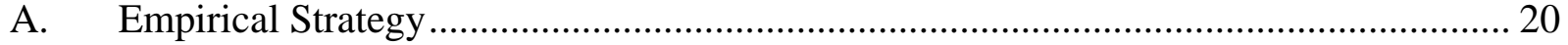

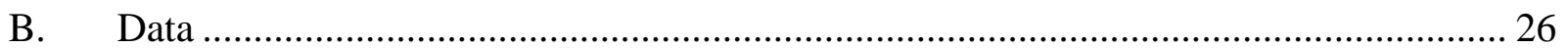

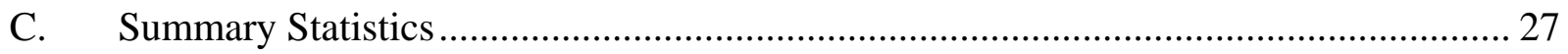

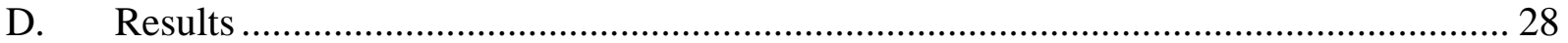

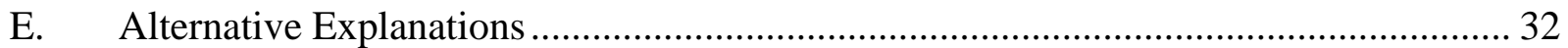

V. Understanding the Mechanism: a Case Study on Connecticut ............................................ 35

A. The Connecticut Story ................................................................................................. 36

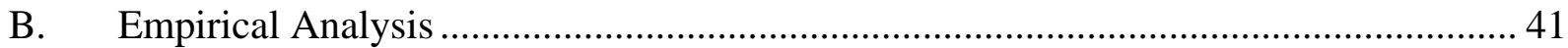

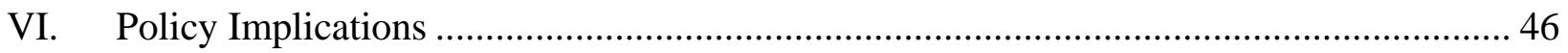

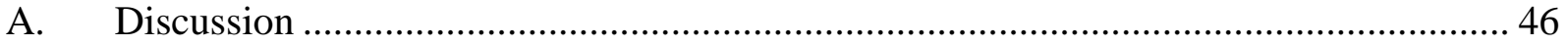

B. Implications for the Value of Place-Based Policies ......................................................... 49

C. Policy Implications................................................................................................... 52

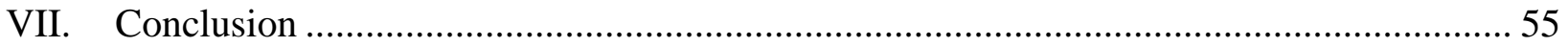




\section{Introduction}

In the United States, if a middle-class person wants to live in a large city, she often must pay high taxes in exchange for receiving low-quality services. ${ }^{2}$ This feature of local government law results from the combination of local financing and a large presence of poor residents in central cities, which have a $19 \%$ poverty rate compared to only a $7.5 \%$ poverty rate in suburbs. ${ }^{3}$ These poor residents pay less in taxes and consume more of government spending than middleclass residents, leaving middle-class residents footing the bill for taxes and receiving lower services in return. Simple economic theory predicts that this system of local federalism which "bundles” high taxes and poor services into location choice distorts people who would otherwise live in cities away from their preferred choice, yielding inefficient residential locations. This paper is the first to measure how much the American system of local financing distorts residents’ location decisions.

To measure the extent of the distortion arising from the bundling of city living with high taxes and low services, I take advantage of a "natural experiment” in local government financing. In particular, the past few decades have seen a virtual revolution in the financing of cities, as state governments have started redistributing vast amounts from rich suburbs to poorer cities primarily through aid to schools-in other words, partly undoing the dependence on local funding for local services in some places. ${ }^{4}$ Since the 1970 s, courts in many states and

\footnotetext{
2 Joseph Gyourko, Place-Based Aid Versus People-Based Aid and the Role of an Urban Audit in a New Urban Strategy, 3 CitysCAPE 305 (1998) and Janet R. Pack, Poverty and Urban Public Expenditures, 35 URB. STUD. 1995 (1998).

${ }^{3}$ See Edward Glaeser, Matthew Kahn \& Jordan Rappaport, Why do the Poor Live in Cities?, 63 J. URB. ECon. 1, 1 (2008).

${ }^{4}$ The legal literature on school finance litigation is vast. See e.g., Peter Enrich, Leaving Equality Behind: New Directions in School Finance Reform. 48 VAND. L. Rev. 100 (1995), Carlee Poston Escue, William E. Thro \& R. Craig Wood, Some Perspectives on Recent School Finance Litigation, 268 EdUc. L. REP. 601 (2011), Michael
} 
legislatures in others have mandated vastly increased state spending in poor school districts in order to reduce large inequalities in spending across poor and rich locations. ${ }^{5}$ For example, New Haven, CT, in 1999 received \$1,405 per resident (not per student) from the state government for schools, while its rich suburb Orange received a comparatively miniscule $\$ 64$ per resident. ${ }^{6}$ This is a stark change from 1970, when New Haven received \$193 per resident (in inflation-adjusted 1999 dollars) and Orange received \$304 per resident. In aggregate, vast sums of money are at stake and have increased substantially with time; in 2000, state governments spent $\$ 347$ billion on elementary and secondary education, more than doubling from the 1972 spending of \$158 billion (in 2000 dollars). ${ }^{7}$

My hypothesis is that these large sums of money for schools have caused at least one of three outcomes: improved school services, improved non-school services, or reduced tax rates; as a result, more residents have been drawn to live in poor cities. In other words, an unintended consequence of school finance equalization has been making poor places more desirable places to live, perhaps largely for reasons other than improving schools_-and thereby increasing their populations. This hypothesis comports with the observation that there has been a "return to the

Heise, State Constitutional Litigation, Educational Finance, and Legal Impact: An Empirical Analysis, 63 U. CIN. L. REV. 1735 (1994), Michael Heise, State Constitutions, School Finance Litigation, and the "Third Wave": From Equity to Adequacy, 68 Temp. L. ReV. 1151 (1995), Michael Heise, Equal Educational Opportunity, Hollow Victories, and the Demise of School Finance Equity Theory: An Empirical Perspective and Alternative Explanation, 32 GA. L. Rev. 544 (1997), Gail F. Levine, Meeting the Third Wave: Legislative Approaches to Recent Judicial School Finance Rulings, 28 HARV. J. ON LEGIS. 507 (1991), Kevin R. McMillan, The Turing Tide: The Emerging Fourth Wave of School Finance Reform Litigation and the Courts' Lingering Institutional Concerns, 58 OHIO ST. L.J. 1867 (1997), Douglas S. Reed, Twenty-Five Years after Rodriguez: School Finance Litigation and the Impact of the New Judicial Federalism, 32 L. \& Soc'Y ReV. 175 (1998), William E. Thro, To Render Them Safe: The Analysis of State Constitutional Provisions in Public School Finance Reform Litigation, 75 VA. L. REV. 1639 (1989), William E. Thro, The Third Wave: The Impact of the Montana, Kentucky, and Texas Decisions on the Future of Public School Finance Reform Litigation, 19 J.L. \& EDUC. 219 (1990).

${ }^{5}$ For a list of state court decisions, see School Finance Litigation, By Year, Case, and Status, By State: 1970 - 2009, NATIONAL CENTER FOR EDUCATION STATISTICS, http://nces.ed.gov/edfin/litigation.asp (last visited Dec. 5, 2013). For an overview from the economics perspective, see David Card \& Abigail Payne, School Finance Reform, the Distribution of School Spending, and the Distribution of Student Test Scores, 83 J. PUB. ECON. 49 (2002).

6 These statistics are my calculations of data from Annual Survey of Governments, NATIONAL BUREAU OF ECONOMIC RESEARCH, http://data.nber.org/asg/ASG_release/ (last visited Sept. 28, 2013).

${ }^{7}$ Id. 
city" in recent decades. ${ }^{8}$ Indeed, the share of the U.S. population in cities reached its nadir in 1980, around the time that state school finance redistribution started flowing to poor cities. Since 1980, central cities have grown so fast that they have not only maintained their share of the national population but actually increased it. In 2010, 33\% of the U.S. population lived in central cities, the highest proportion since $1950 .^{9}$ I offer and test a new explanation for this phenomenon: a change in laws which has favored cities.

I take two approaches in the paper. First, using Census data of all cities, towns, and other Census-designated places, (which I collectively call “places”), I study whether locations that have received greater amounts of school redistribution have had a higher population growth rate. To do so, I address two biases which confound accurate measurement of the effect of financial transfers on population growth. First, poor places' populations tend to grow more slowly, since they are less productive and therefore attract fewer residents. ${ }^{10}$ They also receive more school finance funds, so that naïve analysis may show that the receipt of school finance funds decreases population growth. To address this “poor place bias," I control flexibly for places’ initial income

\footnotetext{
${ }^{8}$ See, e.g., Return to the City, PLANETIZEN.COM, http://www.planetizen.com/node/36734 (last visited Aug. 15, 2013) (containing a series of articles on the "return to the city") and LeIGH Gallagher, THE END OF THE SuBURBS: WHERE THE AMERICAN DREAM IS MOVING (2013) (arguing that there has recently been a renaissance in American cities).

${ }^{9}$ Mark Mather, Kelvin Pollard \& Linda A. Jacobsen, Reports on America: First Results from the 2010 Census, POPULATION REFERENCE BUREAU 15 (July 2011), http://www.prb.org/pdf11/reports-on-america-2010-census.pdf (using data from Demographic Trends in the 20th Century, U.S. CENSUS BuREAU (Nov. 2002), http://www.census.gov/prod/2002pubs/censr-4.pdf). The country's 554 central cities are defined by the Office of Management and Budget and "generally consist of one or more of the largest population and employment centers of a metropolitan area." Central Cities of Metropolitan Areas, U.S. CENSUS BuREAU (Jan. 28, 2002), http://www.census.gov/population/estimates/metro-city/cencty.txt.

Note though that Joel Kotkin holds the contrary view that there has been no return to the central city, partly because he cuts Census data differently than the Census itself does or is talking about employment, not residential population. See Joel Kotkin, The Triumph of Suburbia: Despite Downtown Hype, Americans Choose Sprawl, THE DAILY BEAST (Apr. 29, 2013, 4:45 AM), http://www.thedailybeast.com/articles/2013/04/29/the-triumph-ofsuburbia-despite-downtown-hype-americans-choose-sprawl.html (noting that, "in 91 of America's 100 biggest metro areas, the share of jobs located within three miles of downtown declined over the 2000s) and Joel Kotkin, America's Fastest-Growing Counties: The 'Burbs Are Back, ForBES (Sept. 26, 2013, 10:00 AM), http://www.forbes.com/sites/joelkotkin/2013/09/26/americas-fastest-growing-counties-the-burbs-are-back/ (noting that most of the fastest-growing counties are in suburban or exurban areas).

${ }^{10}$ Of course, there are other potential causal mechanisms, and the bias could go the other way. However, the analysis below confirm that the bias goes in this direction.
} 
level. Second, states may have grown at differential rates even in the absence of school finance redistribution. For example, Sun Belt states grew very rapidly from 1980 to 2010, and some Sun Belt states also redistributed little, so that naïve analysis may again suggest that the receipt of school finance funds decreases growth. To address this "state bias," I control for each state. With these controls, I effectively implement a “differences-in-differences" econometric approach, comparing population growth among places with the same initial income level, but differing amounts of redistribution because they are in different states.

These results suggest that school finance redistribution has played a large role in increasing the growth rates of poor cities in states with large amounts of redistribution. In particular, the results mean that, in a state with the average amount of redistribution, population growth was 7.68 percentage points higher between 1980 and 2010 in a poor place at the $10^{\text {th }}$ percentile of the income distribution relative to a rich place at the $90^{\text {th }}$ percentile of the income distribution because of the redistribution. This difference is nearly half the average place's growth rate of 17.22 percentage points.

Second, to better understand the mechanisms involved, I study local finances in Connecticut in particular. ${ }^{11}$ I first show how there has, indeed, been a revolution in local finances for the poorest places in Connecticut, with the share of local finances funded by the state nearly doubling to half of all revenue between 1972 and 1999, while the share of revenue from the state has declined substantially for wealthy communities. I then trace how the state transfers are used, documenting an unintended consequence of school finance litigation: a substantial amount is used to reduce taxes not to improve the intended service, spreading the benefits of the revenue across the locality.

\footnotetext{
${ }^{11}$ For a review of the Connecticut experience, see Lauren A. Wetzler, Buying Equality: How School Finance Reform and Desegregation Came to Compete in Connecticut, 22 YALE L. \& POL'y REV 48 (2004).
} 
Finally, I discuss policy implications of this research. In particular, these results strengthen the argument that local financing of services distorts people away from living in the locations which would maximize overall utility for two reasons. First, the results show that, when state governments move toward leveling the local finance playing field, there is a substantial mobility response. This means that the "bundling" of high taxes and low-quality services together in poor central cities causes a substantial distortion in location choices relative to the private optimum - that is, where people would choose to live if the services bought with taxes were the same in cities and suburbs. Second, there are many reasons to think that there are substantial positive externalities to living in cities—including reduced greenhouse gas emissions and agglomeration benefits—meaning that the current tax regime distorts location decisions even further from the social optimum than the private optimum. That is, the disincentive to live in cities is particularly perverse because the presence of positive externalities suggests that social welfare is maximized when even more people live in cities than would choose to do so on their own without any disincentives. Overall then these results support the use of place-based policies_of which school finance redistribution is an important, if previously unrecognized, example - targeting particular geographies instead of particular people. As a result, the paper suggest that states and the federal government should increase their aid to poor localities to reduce the distortion to residential location choice resulting from the uneven local finance playing field. In other words, more redistribution would be not only equitable but also efficient.

After discussing the relation of this paper to existing literature in Section II, I develop the theory for why population would be affected by state transfers in Section III. Section IV describes the empirical strategy, data, and results of the national analysis of the effect of state transfers on population growth. Section $\mathrm{V}$ describes the empirical strategy, data, and results of 
the analysis of Connecticut local finances. Section VI describes potential policy implications, especially relating to the value of place-based policies and structure of taxes funding local services, and Section VII concludes.

\section{Contribution to How Cities Work and How City Government Should Be Structured}

This work contributes to four existing strands of literature-on two sets of positive questions and two sets of normative questions. The first set of positive questions concerns both why there seems to have recently been a "return to the city" and also why there was so little development in cities and so much sprawl in the second half of the twentieth century. Second, this paper sheds light on the assumptions underlying the Tiebout model. It then sheds light on two normative questions_-on the optimal structure of local government and, more importantly, on a subset of the former question, the optimal structure of taxes funding local government.

\section{A. Positive Questions in Urban Studies}

At its most basic level, this paper proposes a hypothesis and tests it; this is the first empirical study to rigorously test whether reducing the tax burden and improving the services of poor inner cities through state transfers has helped lead to a "return to the city."12 One paper suggests that the overall decline in city living between 1950 and 2000 was counteracted by three factors: increased immigration, delayed childbearing, and a reduction in the fraction of households headed by veterans. ${ }^{13}$ Other proposed explanations for the phenomenon include a shift in preferences in younger generations, rising fuel prices, and demographic shifts leading to

\footnotetext{
${ }^{12}$ For data on the phenomenon, see Mather, Pollard \& Jacobsen, supra note 9. For population media reaction to the phenomenon, see Return to the City, supra note 8. Note that this trend was less visible when only looking through the 2000 Census. See Edward Glaeser \& Jesse Shapiro, Urban Growth in the 1990s: Is City Living Back?, 43 J. REGIONAL SCI. 139 (2003).

${ }^{13}$ Leah Boustan \& Allison Shertzer, Population Trends as a Counterweight to Central City Decline, 50 DEMOGRAPHY 125 (2013).
} 
smaller families which start later. ${ }^{14}$ Still others have suggested that reductions in crime and increased demand for the social interactions that cities provide caused the shift. ${ }^{15}$ I offer a new alternative: courts ordered that states increase subsidies for city living, in the form of school finance redistribution.

This paper also relates to work on why there has been so little new development in seemingly desirable city locations. Edward Glaeser and others argue that zoning and excessive regulation have hindered development. ${ }^{16}$ David Schleicher argues that the multiple veto points allow determined opponents who would bear concentrated losses to stop projects. ${ }^{17}$ Others argue that low school quality and issues like crime discussed above are the cause. ${ }^{18}$ I suggest that it is in part because of tax policy; tax rates are high because of the presence of poverty in cities, discouraging new development.

The work also relates to the analysis on understanding the causes of urban "sprawl." For example, Robert Ellickson argues that suburban growth controls are a primary culprit of sprawl. ${ }^{19}$ William Fischel agrees, adding the mortgage interest subsidies as a secondary

\footnotetext{
${ }^{14}$ See GALLAGHER, supra note 8.

${ }^{15}$ Edward Glaeser \& Joshua Gottlieb, Urban Resurgence and the Consumer City, 43 URB. STUD. 1275 (2006) and Julie B. Cullen \& Steven D. Levitt, Crime, Urban Flight, and the Consequences for Cities, 81 Rev. Econ. \& STAT. 159 (1999) (on the link between the decline of cities and crime).

${ }^{16}$ See EdWARD Glaeser, TRIUMPh OF THE City (2011); Edward Glaeser, Joseph Gyourko \& Raven Saks, Why is Manhattan So Expensive?: Regulation and the Rise in House Prices, 48 J.L. \& ECON. 331 (2005); and Edward Glaeser \& Bryce Ward, The Causes and Consequences of Land Use Regulation: Evidence from Greater Boston, 65 J. URB. ECON. 265 (2008).

${ }^{17}$ David Schleicher, City Unplanning, 122 YALE L.J. 1670 (2013).

${ }^{18}$ See Isaac Bayoh, Elena G. Irwin \&Timothy Haab. Determinants of Residential Location Choice: How Important Are Local Public Goods in Attracting Homeowners to Central City Locations, 46 J. Regional SCI. 97 (2006) and William H. Frey, Central City White Flight: Racial and Nonracial Causes, 44 Am. Soc. REV. 425 (1979).

${ }^{19}$ Robert Ellickson, Monitoring the Mayor: Will the New Information Technologies Make Local Officials More Responsible?, 32 URB. LAW. 391 (2000). See also the seminal analysis of suburban land use controls, Robert Ellickson, Suburban Growth Controls: An Economic and Legal Analysis, 86 YALE L.J. 385 (1977) [hereinafter Ellickson, Suburban Growth Controls].
} 
explanation. $^{20}$ My results imply that sprawl is partly driven by the design of local taxes and services and has been mitigated by the revolution in local financing. ${ }^{21}$

\section{B. Tiebout}

Second, this paper contributes to the literature on the appropriate model for understanding local governments. In particular, it represents an additional critique of the Tiebout model $^{22}$, considered the dominant paradigm ${ }^{23}$ for understanding local government positively and normatively. Charles Tiebout argued that, with an infinite number of cities to choose between and costless mobility between them, each individual will sort into a jurisdiction with individuals identical to himself. As a result, everyone will be provided with his preferred bundle of services, since identical people will demand identical services from their governments. Social welfare will be maximized without any provision of services at a level of government above the city. This decentralized local governance structure may also promote competition among cities in the provision of public services like schools, improving performance. ${ }^{24}$

\footnotetext{
${ }^{20}$ WiLliam A. Fischel, THE HOMEVOTER HyPOTHESIS 229-232 (2001).

${ }^{21}$ This research also relates to research behind explanations for why states expand redistribution. See, e.g., Elizabeth Cascio \& Ebonya Washington, Valuing the Vote: The Redistribution of Voting Rights and State Funds Following the Voting Rights Act of 1965, (Nat'l Bureau of Econ. Research, Working Paper No. 17776, 2012)(showing that the expansion in black voting rights resulting from the Voting Rights Act of 1965 was accompanied by a shift in distribution of state aid toward localities with a disproportionally large black population).

${ }^{22}$ Charles M. Tiebout, A Pure Theory of Local Expenditures, 64 J. Pol. Econ. 416 (1956). The "exit" option in response to undesirable local circumstances - the option suggested by Tiebout-is often contrasted with the "voice" option of improving those circumstances. See also AlfRED HirSCHMAn, EXIT, VoICE, AND LOYALTY (1970).

${ }^{23}$ David Schleicher, The City as a Law and Economic Subject, 2010 U. ILL. L. Rev. 1507, 1507 (2010) (“The study of the relationship between local government law and economics has long had one central text: Charles Tiebout's famous 1956 article, A Pure Theory of Local Expenditures.”) and Richard Briffault, The Rise of Sublocal Structures in Urban Governance, 82 MinN. L. REv. 503, 503 (1997) ("The dominant law and economics model of local government, based on the work of Charles M. Tiebout, assumes that decentralization of power to local governments promotes the efficient delivery of public goods and services.")

${ }^{24}$ See, e.g., Caroline Hoxby, Does Competition among Public Schools Benefit Students and Taxpayers?, 90 Ам. ECon. Rev. 1209 (2000). But see Jesse Rothstein, Does Competition Among Public Schools Benefit Students and Taxpayers? A Comment on Hoxby (2000), 97 AM. ECON. REV. 2026 (2007) (critiquing Hoxby's econometric results as unsound). A further argument in favor of small jurisdictions is that larger governments may have diseconomies of scale. See Richard Briffault, The Role of Local Control in School Finance Reform, 24 ConN. L. REV. 773, 791 (1992) ("In addition to promoting the opportunities for local choice, it has been asserted that local control constrains
} 
The Tiebout model has been critiqued from multiple perspectives. For example, it does not incorporate cross-jurisdictional externalities. ${ }^{25}$ High contracting costs may prevent jurisdictions from contracting to address these externalities. ${ }^{26}$ It does not consider distribution. ${ }^{27}$ As well, an insightful recent discussion emphasizes the trade-off between sorting, or allowing people to move to a jurisdiction with the bundle of government-provided goods that they desire, and "agglomeration," or the benefits from dense development resulting in "reduced transportation cost for goods, increased labor market depth, and intellectual spillovers." ${ }^{28}$ In the paper, David Schleicher argues that there is a trade-off between the two, since the presence of many small governments promotes Tiebout sorting by giving many options to residents, but does not promote optimal agglomeration benefits, since these benefits are felt across jurisdictional boundaries and it may be difficult for a large number of cities to coordinate to maximize them. ${ }^{29}$

Richard Schragger critiques not the assumptions of the Tiebout model but rather its supposed outcome of promoting efficiency and economic growth. ${ }^{30}$ He argues, first, that rather than decentralization causing economic growth, the opposite appears to have been the case, and, second, that the main drivers of economic success have more to do with path dependency and luck than legal institutions like the degree of decentralization. ${ }^{31}$

\footnotetext{
the unit costs of government services. These efficiency benefits derive from the relatively small size and greater homogeneity of most school districts, compared to the state or to possible metropolitan-area-wide districts.”)

${ }^{25}$ See Richard Briffault, Our Localism: Part II - Localism and Legal Theory, 90 CoLuM. L. REv. 346, 426-27 (1990) and Richard Schragger, Consuming Government, 101 Mich. L. REV. 1824, 1834 (2003).

${ }^{26}$ See Clayton P. Gillette, Conditions of Interlocal Cooperation, 21 J.L. \& PoL. 365, 367 (2005) ("My underlying claim . . . is that the most significant obstacles to cooperation lie in high contracting costs."). Various factors increase contracting costs, including difficulty monitoring behavior and courts' reluctance to get involved, especially in budgetary matters. Clayton P. Gillette, Regionalization and Interlocal Bargains, 76 N.Y.U. L. REV. 190, 257-60 (2001).

${ }^{27}$ See Sheryll D. Cashin, Localism, Self-Interest, and the Tyranny of the Favored Quarter: Addressing the Barriers to New Regionalism, 88 GEO. L.J. 1985, 1991-2015 (2000).

${ }^{28}$ Schleicher, supra note 23, at 1507.

${ }^{29}$ Id. at 1512.

${ }^{30}$ Richard Schragger, Decentralization and Development, 96 VA. L. REV. 1837 (2010).

${ }^{31}$ Id., at 1837.
} 
The importance of the assumption tested by my paper has been described elegantly by Richard Briffault, who describes the

blithe assumption that most interlocal tax and spending differences are attributable to differences in "tastes," and not to differences in wealth. In theory, one locality might prefer a municipal golf course, another a new computer lab for its schools, a third might opt to repave its roads, and a fourth might decide to lower taxes and spend less on local services. In fact, however, many local taxing and spending decisions are based not on idiosyncratic local taste differences, but on the stark fiscal disparities that divide localities within each metropolitan area. ${ }^{32}$

What my paper develops is the mechanism that makes this factor a particularly important deviation from reality. This paper emphasizes what results from two important facts: First, poor people disproportionately live in cities. Second, space matters. That is, although people want to live close to their jobs, which are disproportionately in cities ${ }^{33}$, or may want to live in cities for any other reason, the Tiebout model does not have space. It just has an infinite number of autonomous cities, with no commuting between them. Yet, to live in poor central cities, residents must endure worse services and higher taxes. In other words, the American system of local financing "bundles” together high taxes and bad services with city living, discouraging individuals from living in locations which they otherwise would prefer.

This bundling is largely a result of two features of American local government law emphasized by Robert Ellickson. First, state constitutional provisions generally require the

\footnotetext{
${ }^{32}$ Richard Briffault, supra note 24, at 789-790.

${ }^{33}$ Edward L. Glaeser \& Matthew E. Kahn, Decentralized Employment and the Transformation of the American City, 2001 BROOKINGS-WHARTON PAPERS ON URBAN AFFAIRS 1, 6 (2001) (showing that 20\% of people lived within three miles of central business districts in 1996, but 25\% worked there).
} 
provision of "free" elementary and secondary education. ${ }^{34}$ Second, state constitutions generally prohibit differential property taxes. ${ }^{35}$ As a result, residents of a town are "in it together" in a way that they would not be if schools were paid for by state-provided vouchers redeemable anywhere or if enclaves of the rich in a poor city could have lower property tax rates in order to attract them to the city. Similarly, "[w]hen a municipality finances a service from general revenues, it is usually obligated to distribute the benefits of that service in roughly equal shares, irrespective of the general taxes the individual citizen may have paid." ${ }^{36}$ As a result of these factors, if a middle class person wants to live in a central city, he often must pay the "entry fee" of having higher taxes and worse services, leading to a distortion in residential location choice not considered in the Tiebout model.

\section{Design of Local Government}

Having further called into question a dominant theory for how local government work, the third strand of literature this paper contributes to is on the appropriate design of local government. Much has been written advocating the benefits of metropolitan government over fragmented jurisdictional control within metropolitan areas. This view suggests that metropolitan decentralization may lead to sprawl and inequality. ${ }^{37}$ Gerald Frug argues that "current urban policy adopted by every level of American government promotes the fragmentation of America's metropolitan areas" and that having metropolitan-level “communities” would be superior. ${ }^{38}$ To my knowledge, little has been written on the aspect I

\footnotetext{
${ }^{34}$ Ellickson, Suburban Growth Controls, supra note 19, at 452

${ }^{35} \mathrm{Id}$.

${ }^{36} I d$. at 455.

37 See, e.g., Anthony Downs, New Visions for MEtropolitan AmericA (1994) and Myron Orfield, Metropolitics: A REgionAl AGENDA FOR COMMUNiTy AND STABILITY (1997).

${ }^{38}$ Gerald Frug, The Geography of Community, 48 STAN. L. REV. 1047 , 1047 (1995) (“The federal government's support for highways and home ownership, like the state-created rules of local government law, nurtures suburban
} 
highlight here- - how differential taxation within a metropolitan area leads to a tax-dispreferred status for cities.

However, while ultimately this paper reveals additional deficiencies in the current decentralized make-up of metropolitan governments, the structure of local governments is a larger issue than the structure of local finances. This is a paper about equalizing funding of local governments. Consolidating metropolitan areas into single governments would likely do much more than that-changing how money is spent for schools and other city services, how land is zoned, and conceivably the whole range of local functions. As a consequence, the evidence here is more relevant to the question of overall government structure. The results here support metropolitan consolidation because the "tax" on central city living would be reduced by such consolidation. However, the issue of location distortion is just one among many important issues.

\section{Design of Local Government Finances}

This paper contributes most strongly to a component of the appropriate design of local government, the design of local government financing, especially as it relates to schools. While the Tiebout model largely explains the benefits of local financing, Richard Briffault discusses many of the downsides to local control of school finances. He points out three ways in which local financial control contributes to inequality in the provision of local education. ${ }^{39}$ The first is the most obvious; by "dividing states into districts of radically different taxable wealth, . . . the quality of local services [is] dependent upon the amount of local wealth.” ${ }^{40}$ The second way is

autonomy, while the suburbs use their zoning power, and central cities their redevelopment authority, to isolate the poor in general and racial minorities in particular.”).

${ }^{39}$ Briffault, supra note 24.

${ }^{40} I d$., at 805 . 
more subtle: local financial control "reinforces the consequences of the initial inequality by creating a regional 'centrifugal force,' that leads the affluent to physically segregate themselves from the less affluent, to deploy local land use powers to heighten the barriers to local economic integration, and to incorporate separately so as to protect local wealth and immunize local taxpayers from regional fiscal needs and demands. ${ }^{21}$ This kind of feedback loop is part of what this paper is testing for. But what I emphasize after finding evidence that people change locations when funding is equalized is that this "centrifugal force" is not only an issue of equality, but also of efficiency. In particular, individuals may prefer to live in cities for a variety of reasons, including living nearby work, but do not do so because of the local financing of services. Third, Briffault argues that "local financial responsibility may 'skim off' the ablest, most active, and most effective parents from inner city communities that need them most, thereby leaving those communities not only with fewer economic resources, but bereft of the political resources necessary to secure the accountability of local political institutions and to empower local participation." ${ }^{42}$ Relatedly, as argued by William Julius Wilson, the absence of middle-class black professionals may especially harm the prospects for the black youths who remain in central cities. ${ }^{43}$ These arguments emphasize the complex types of feedbacks which can occur with local finance redistribution. Once finances move toward equalization, the middle-class may return to cities, generating endogenous political responses, which improve services, and attract more middle-class individuals. Again, I will emphasize the efficiency aspect of this response. ${ }^{44}$

\footnotetext{
${ }^{41} I d$.

${ }^{42} I d$., at 805-806.

${ }^{43}$ William Julius Wilson, The Truly Disadvantaged (1987).

${ }^{44}$ For the return of the middle class to the cities to be efficient, of course, there must not be offsetting efficiency losses resulting from their leaving the suburbs.
} 
Within this discussion on the theoretical background of the costs of unequal funding, there has been a debate about the empirical effects on the most well-studied school finance equalization scheme, California's. In Serrano v. Priest, 5 Cal.3d 584 (1971), the California Supreme Court held that the state's local financing of schools violated the California and U.S. Constitutions' equal protection requirement. After the state legislature acted to equalize education funding, state voters passed Proposition 13, which limited the local property tax to $1 \%$ of property value, among other changes including those affecting how property was valued. ${ }^{45}$ Fischel has argued that Serrano caused Proposition 13, by reducing the amount that a locality benefited from paying its local taxes. ${ }^{46}$ As a result, Fischel argues, the endogenous political response to school finance equalization has served largely to limit school funding. I combine school finance reforms across the country in my empirical analysis, both those like California and those unlike it. I also focus on the school finance reform of Connecticut, which does not exhibit the problems that California's has; in particular, if towns in Connecticut choose to spend more on education, they keep the full amount of increase in tax revenue for their own locality.

The analysis here also offers some insight into one part—perhaps the largest part—of the debate over the local financing of services, the property tax. Edward Zelinsky, once a strong critic of the local property tax and now a more moderate critic, offers one of the most thoughtful analyses on the local property tax and neatly summarizes current thinking on the issue. ${ }^{47} \mathrm{He}$ argues that two intellectual developments have challenged the critique of the property tax as,

\footnotetext{
${ }^{45}$ CAL. CONST art. 13A.

${ }^{46}$ William Fischel, How Serrano Caused Proposition 13, 12 J.L. \& PoL. 607 (1996). But see Kirk Stark \& Jonathan Zasloff, Tiebout and Tax Revolts: Did Serrano Really Cause Proposition 13?, 50 UCLA L. Rev. 801 (2003) (challenging the claim of Fischel by offering a different empirical assessment) and William Fischel, Did John Serrano Vote for Proposition 13? A Reply to Stark and Zasloff's “Tiebout and Tax Revolts: Did Serrano Really Cause Proposition 13?”, 51 UCLA L. REV. 887 (2004) (defending the original proposition that Serrano caused Proposition 13).

${ }^{47}$ Edward Zelinsky, The Once and Future Property Tax: A Dialogue with My Younger Self, 23 CARdOzo L. ReV. 2199 (2002).
} 
among other things, inequitable. ${ }^{48}$ First, research in economics by Harberger suggests that the ultimate "incidence" of taxes may not be borne by those who pay them-meaning that the tax cost of the property tax may be largely borne by owners of capital (e.g., those owning stock in corporations), not renters or homeowners of modest means. ${ }^{49}$ Second, Zelinsky notes that " $[t]$ he alternative challenge to the traditional wisdom, premised on the seminal writings of Charles Tiebout, views the property tax as a wash: the payment of property taxes purchases offsetting benefits in the form of government services." ${ }^{, 50}$ Nevertheless, Zelinsky argues that "[p]arts of the critique retain force. Concerns about regressivity remain insofar as the tax is passed onto tenants or is absorbed by homeowners of modest means." ${ }^{51}$ As well, "despite the disappointing gap between increased funding and improved student performance, persuasive reasons exist for allocating to the states a strong role in financing public education." ${ }^{\text {52 }}$ To this cogent reappraisal of the local property tax, I add another critique: the local property tax distorts where people live, hurting not only individuals but also society because of the higher-externality lifestyle associated with living outside of cities. Overall then this research contributes to critiques of unequal school funding and the local property tax structure which underlies this differential.

\section{Theory}

In this section, I reduce the world down to its barest essentials and develop a model to guide the understanding of the empirical results. Consider a typical poor city, which has a disproportionately large number of poor people because of access to public transit or other

\footnotetext{
${ }^{48} I d$. at $2201-2203$.

${ }^{49} I d$. at 2204.

${ }^{50} I d$. at 2205.

${ }^{51} \mathrm{Id}$.

${ }^{52} I d$. at 2209.
} 
reasons. ${ }^{53}$ Suppose that, in time period 1 , a poor city receives little funding from the state government. Likely there will be relatively bad services and a high property tax rate in the city because the poor are unable to pay much in taxes. As a result, a potential resident who is welloff likely faces higher tax rates and assessments in the central city than in the suburbs. As well, the higher taxes and lower service levels capitalize into land values, further driving down land values and driving up rates. Since any new development would face that high property tax assessment, in addition to the poor services, housing demand is relatively low. Figure 1 graphically represents the poor central city. ${ }^{54}$ The housing market in the city at time period 1 is described by the Housing demand ${ }^{1}$ and Housing supply lines, resulting in home price $P^{1}$ and quantity of homes $Q^{1}$.

Figure 1: Effect of a Shift in Housing Demand from Increased Transfers

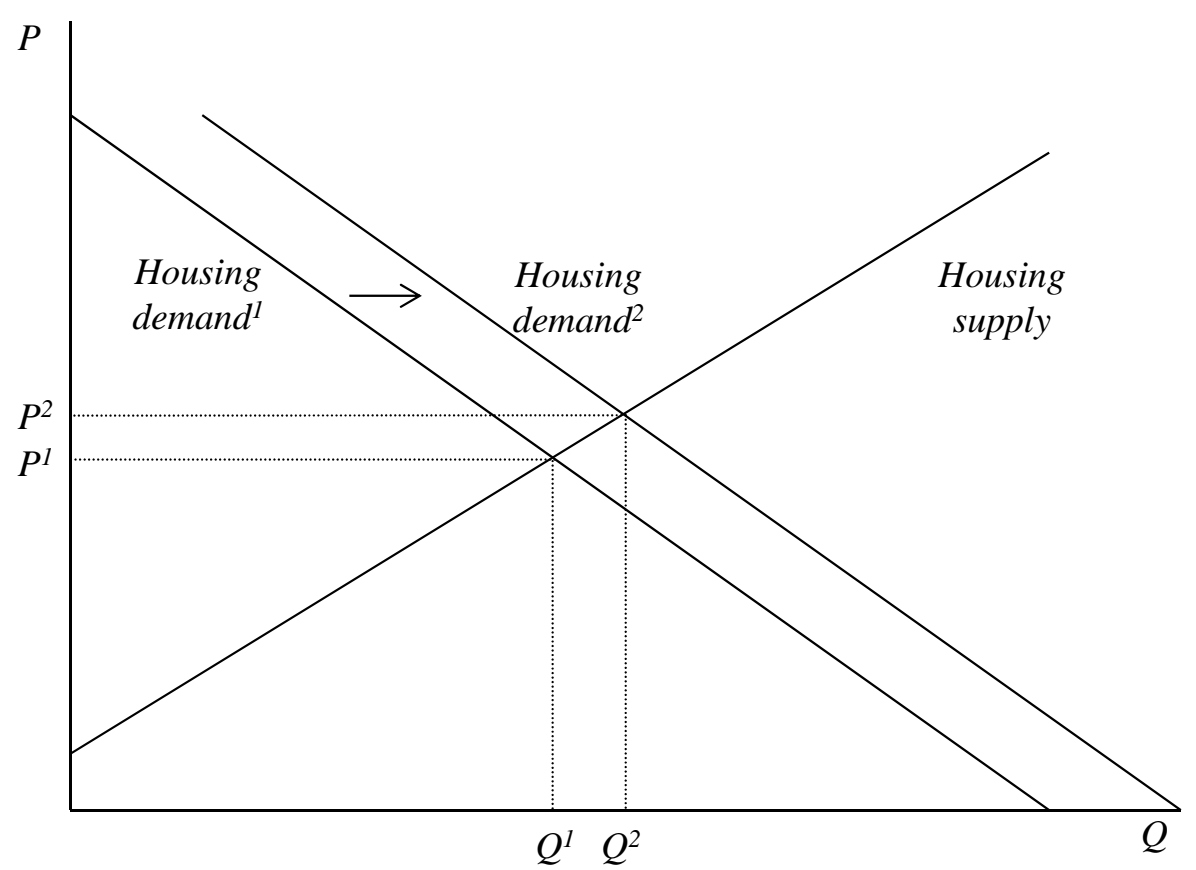

53 Glaeser, Kahn \& Rappaport, supra note 3.

54 The housing quantity can be thought of consisting of "housing unit-equivalents," which converts houses of different sizes into a uniform measure. See Jerome Rothenberg, George C. Galster, Richard V. Butler \& John R. Pitkin, The MaZe of Urban Housing Markets: TheOry, EvidenCe, And Policy (1991). 
But now suppose that the state starts redistributing money to poor cities, improving services and lowering tax rates. Unless the housing supply is perfectly inelastic or elastic, this change will do two things. ${ }^{55}$ First, it will increase property values for the existing housing supply, since the city will be a more desirable place to live. This is known as "capitalization" into property values. Second, people will build more homes on undeveloped land (and renovate old ones in a more complicated model), allowing more people to move to the city, attracted by improved services or reduced tax rates. These changes are represented by the outward shift in housing demand to Housing demand ${ }^{2}$, resulting in an increase in home price to from $P^{1}$ to $P^{2}$ (the capitalization) and increase in the quantity of homes to $Q^{2}$, with $Q^{2}-Q^{1}$ new homes built.

It is important to emphasize the role of capitalization. In particular, the easier it is to build new housing, the flatter the housing supply line is, and the less capitalization there is into housing prices. One can see this by imagining that the housing supply line is perfectly horizontal (i.e., housing supply is “infinitely elastic,” or infinitely responsive to changes in price). Then, $P^{2}$ will be the same as $P^{1}$, and there will be no capitalization at all. In contrast, if the housing supply line is perfectly vertical (i.e., housing supply is “infinitely inelastic”), there will be no change in quantity and all of the change will be in price-all the benefit of the increased state funding will be capitalized into housing prices. Note then that a larger housing quantity response goes along with a smaller capitalization response, all else equal. This paper studies the change in housing quantity, which should respond to redistribution if housing supply is not perfectly inelastic.

One way to think about the situation is that there are two pieces of undeveloped land, identical except that each is on a different side of a municipal boundary. One side is a poor city

\footnotetext{
${ }^{55}$ This analysis assumes that housing demand is downward-sloping, as in the figure.
} 
with high property tax rates and bad schools and the other side is a rich suburb with low property tax rates and good schools. The land will cost more on the suburban side, since the value of good schools and lower taxes will be capitalized into it. Suppose that someone who works downtown is moving to the area and is deciding which side of the border to build a house on. Assuming he values the good schools, he will probably build on the suburban side despite the higher land prices, since he values the schools and he will face lower property taxes there. The question this paper asks is to what extent improving services and lowering taxes in the poor city encourages future builders to put their houses on the city side of the border. Of course, there is little distortion to location choice when deciding which side of a border to live on; the real question is how elastic people's decisions are. If the effects measured here are small, it will appear that people are only willing to make small changes in response to fiscal infusions into cities-they are only willing to jump over the border. If the effects are large, then people who would have lived far away presumably are moving into the city.

\section{National Empirical Analysis}

\section{A. Empirical Strategy}

When measuring the effect on population growth of redistribution across communities of different income levels, a key concern is that communities of different income levels may have been growing differentially in the first place. As a result, it is desirable to compare similar cities in states with different amounts of redistribution. Then, as long as income does not have a different effect on population growth in different states for reasons other than differential state redistribution, the results are valid. Consider the example in Table 1, a 2x2 table with two states, each of which has a relatively poor place and a relatively richer remainder of the state. 
Essentially, the goal of the empirical part of this paper is to see if population growth rates between 1980 and 2010 follow a particular pattern. I measure whether relatively poor cities like Colorado Springs in high-redistribution states like Colorado tend to have population growth rates relative to the rest of the state which are higher than similar cities, like Salt Lake City, in lowredistribution states like Utah, relative to the rest of their states. In other words, I measure whether poor places in high-redistribution states have had surprisingly high population growth rates - that is, whether the "return to the city" has disproportionately taken place in highredistribution states.

Table 1: Population Growth Rate, 1980 - 2010

\begin{tabular}{l|l|l|l}
\hline \multicolumn{2}{c|}{ Poor place } & Richer rest of state & Difference \\
\hline High-redistribution state & $\begin{array}{l}\text { Colorado } \\
\text { Springs, CO } \\
(93 \%)\end{array}$ & $\begin{array}{l}\text { Rest of Colorado } \\
(72 \%)\end{array}$ & $21 \%$ \\
\hline Low-redistribution state & $\begin{array}{l}\text { Salt Lake City, } \\
\text { UT (14\%) }\end{array}$ & $\begin{array}{l}\text { Rest of Utah } \\
(99 \%)\end{array}$ & $-85 \%$ \\
\hline
\end{tabular}

Difference in differences: $106 \%$

Consider how this two-by-two grid addresses the two biases key to measuring the effect of school finance redistribution. First, suppose that we had two datapoints in the highredistribution state of Colorado: the "experimental" city of Colorado Springs and the rest of the cities in Colorado as a control. Comparing within-state removes the "state bias" resulting from the fact that the Coloradan population would have grown substantially even absent school finance redistribution. So the way to calculate the effect of redistribution on the population growth of Colorado Springs is to begin with the population growth of Colorado Springs and then subtract off the population growth of the "control" places. But a problem remains: relatively poor central cities themselves may have had a certain trend in population growth unrelated to 
redistribution, "poor place bias." 56 So, the population growth of Salt Lake City needs to be subtracted from the population growth of Colorado Springs as well. And then, as with Colorado, the population growth of Utah needs to be subtracted from the population growth of Salt Lake City to address the concern that Utah may have had a certain population growth trend. This analysis leads to the following calculation: (Population growth rate of Colorado Springs Population growth rate of the rest of Colorado) - (Population growth rate of Salt Lake City Population growth rate in the rest of Utah). Conducting this analysis reveals that, while Colorado Springs's growth rate of 93\% exceeded that of Colorado (72\%) by 21 percentage points, Salt Lake City's surprisingly slow growth rate of $14 \%$ was 85 percentage points less than that of Utah as a whole (99\%). Subtracting from excess growth of Colorado Springs over that of Colorado the analogous number for Salt Lake City yields a 106\% excess growth for Colorado Springs — in other words, a doubling of population.

Of course, attributing this doubling of population all to school finance redistribution in this two-city example is not credible. Though Colorado Springs and Salt Lake City had similar 1980 populations (215,000 and 163,000 respectively), had similar 1980 median incomes (\$16,000 and $\$ 13,200$, respectively), and are in the same region, the cities are different in many ways. I could have used other examples. Why did Kansas City, Kansas, grow more quickly than Kansas City, Missouri? Why did Tallahassee grow more quickly than Birmingham, Alabama, or Jackson, Mississippi? Why did Grand Rapids, Michigan, grow more quickly than Canton, Ohio?

\footnotetext{
${ }^{56}$ An additional example of "poor city bias," motivating the multi-state empirical strategy, is illustrated by the example of local restrictions on housing development. In particular, there is evidence that liberal places restrict housing development more than conservative places. Matthew Kahn, Do Liberal Cities Limit New Housing Development? Evidence from California, 69 J. URB. ECON. 223, 223 (2011). Liberal places also likely receive more funding for education, since liberal places often have high poverty rates and therefore receive more school funding from states. Thus, looking only within state, it may look like school financing had little effect on population growth, whereas the financing could actually have a positive effect which is just confounded by the negative effect of having housing-restricting liberals running many of the cities receiving large amounts of funding. Comparing across states, between ones that redistribute a lot and ones that redistribute a little, alleviates this concern.
} 
Why did Portland or Salem, Oregon, grow more quickly than Seattle or Tacoma, Washington? Why did St. Louis, Missouri, grow more slowly than Chicago? In all of these cases, the highgrowth poor city was in the higher-redistribution state. In each case, though, the cities are different. The usefulness of having a dataset with 20,000 places is that many of these idiosyncratic differences average out. As long as systematically across the country poor places in high-redistribution states did not have some economic reason to out-perform poor cities in low-redistribution state, these idiosyncratic differences between places will not matter.

The main empirical analysis in this paper is essentially a version of this four-city example with over 20,000 datapoints. I use regression analysis to relate the same variables above statistically. The large number of datapoints adds precision to the results, and the ability to compare across many states reduces concerns of bias. As in the example, the outcome variable is the population growth rate-in this case, the logarithm of population between 1980 and 2010 $\left(\Delta \log\right.$ population $_{p}$ ), a measure of the population growth rate. ${ }^{57}$ The first explanatory variableand the one with the effect that we are most interested in—is the effect of being a poor city in a high-redistribution state. To create this variable in the regression, I "interact" (i.e., multiply together) the 1980 median income of the place (median_income ${ }_{p}$ ) and the amount of redistribution its state engages in (redistribute s $_{s}$. Correctly measuring the effect of this variable is the goal of the regression, like the goal of measuring the effect of redistribution on population growth in Colorado Springs. Then, as in the example above, I subtract off the population growth in the rest of each state. This means adding "fixed effects" for each state $\left(I_{s}\right)$; in other words, I

\footnotetext{
${ }^{57}$ Taking the logarithm is common in economics and serves two purposes: first, it allows the results to be interpreted as changes in growth rates rather than levels, and second, it reduces the influence that statistical outliers have on the results.
} 
put into the regression a variable for each state. ${ }^{58}$ As a result, the average population growth rate in Colorado will be subtracted off of the growth for the places in Colorado, and the same will be true of every other place and state. Finally, like I needed to subtract the growth of Salt Lake City from that of Colorado Springs, I need to control for the population growth of places of similar income. So, I control for the 1980 median income (median_income ${ }_{p}$ ) of the place. This is the same variable that I used in the interaction term, but here the variable enters the regression alone. In the $2 \times 2$ grid example, I also needed to subtract the population growth of Utah as a whole; the state "fixed effects" do exactly this.

The following regression results from the combination of these variables:

$\Delta \log$ population $_{p}=\beta_{1}$ redistribute $_{s} \cdot$ median_income ${ }_{p}+I_{s}+\beta_{2}$ median_income $_{p}+\varepsilon_{p}$

I have explained what each of these variables means with the exception of the "error term," $\varepsilon_{p}$, with which. the model acknowledges that the variables included in the regression will not fully explain the differences in population growth across 20,000 places. The $p$ subscript indicates that there is a different value for each place. The $s$ subscript indicates that there is a different value for each state. In other words, I am measuring the effect of the interaction between how much a state redistributes and a place's median income on the change in log population in that place (approximately the percent change), controlling for a place's median income and the place's state. $^{59}$

\footnotetext{
${ }^{58}$ Note that normally interaction terms require that both terms in the interaction are separately controlled for. Here, I control for median income, but not state-level school redistribution. However, controlling for state fixed effects controls for not only differences between states in school redistribution but also all other differences between states.

${ }_{59}$ Another way to think about the equation is as the reduced-form regression that would result if the endogenous variable were actual state transfers and the interaction of the measure of state-level redistribution and median
} 
The key product of this regression is the coefficient $\beta_{1}$. This is the effect of the "interaction term" of the amount of redistribution in a state and the place's median income. Following the theory in Section III, we predict $\beta_{1}<0$, since in states with more redistribution, the effect of having a higher 1980 income should be more negative because richer places receive less state funding in those states. In other words, in states like Utah, with little school finance redistribution, the growth rate of poor places like Salt Lake City should be slower relative rest of the state than the growth rate of poor places like Colorado Springs relative to the rest of Colorado.

When evaluating the methodology, consider the "identifying assumption" required for the results to be valid. Essentially, this methodology is a continuous version of a "differences-indifferences" regression, measuring the difference in an outcome between poor treated places and rich, control places in high-redistribution treated states versus low-redistribution control states. Viewed this way, the identifying assumption is just the familiar "common trends" assumption for any differences-in-differences regression. The identifying assumption here can be simply stated then: the difference in population growth rates between big poor places and small rich places would have been the same within high-redistribution states as within low-redistribution states in the absence of school finance redistribution. Finally, it is important to note that this is a paper about the return to the city, yet the analysis primarily concerns whether increased transfers to poor places increases their populations. The reason that subsidizing poor areas also leads to a return to the city is that cities are disproportionately poor. As noted above, cities have

income were an instrument. A benefit of not using actual transfers is that those could be "endogenous" to political decisions to, for example, target particularly needy cities. This could bias the results toward zero if these needy places would have had particularly low growth rates in the absence of redistribution, since it would appear that poor places in high-redistribution states had low growth rates. The overall slope line for each state is less likely to subject to these concerns because it largely removes within-state city-to-city variations. 
substantially higher poverty rates than suburbs. ${ }^{60}$ Viewed differently, regressing 1980 log population (multiplied by 100) on 1980 median household income (divided by \$1,000) yields a coefficient of $-9.18(t=4.48, p=0.000)$, meaning that, on average, when a place's median household income goes up by $\$ 1,000$, its population goes down by $9.18 \%$. That is, on average, richer places have substantially smaller populations.

\section{B. Data}

I assemble data from two sources to run this regression. First, I use data from the Decennial Census, which collects data at the "place” level. Places are usually cities or towns, but also may be unincorporated areas recognized as places for Census’s statistical purposes. ${ }^{61}$ I use three variables from the Census, population in 1980 and 2010 and median household income in $1980 .^{62}$ I use 1980 because it is the earliest date at which a nearly comprehensive database of places is available from the National Historical Geographic Information System, my source of Census data. $^{63}$ I study the 30 -year change because responses to changes in redistribution are likely to be very slow. The changes must be recognized, houses must be built, and people must move. Perhaps more importantly, feedbacks resulting from the "return to the city" may be even slower. For example, drawing in higher-income residents who themselves improve the tax base or more politically active individuals who improve local politics could take many years. ${ }^{64}$

\footnotetext{
${ }^{60}$ Glaeser, Kahn \& Rappaport, supra note 3.

${ }^{61}$ Note that the "place" level may not be the level of government which receives the transfer from the state. For example, in unincorporated areas, there may be no entity to receive such a transfer. However, places are contained within areas that do receive such transfers, and the place level is recognized throughout the country by the U.S. Census.

${ }^{62}$ The fact that household size has shrunk over time will not affect the results as long as household size does not both 1) change differentially in poor places in states with high redistribution versus other places and 2) affect the population growth of those places.

63 NATIONAL HiSTORICAL GEOGRAPHIC INFORMATION SySTEM, https://www.nhgis.org/ (last visited Aug. 10, 2013).

${ }^{64}$ See Briffault, supra note 24, at 805-806.
} 
Second, as a measure of how much states redistribute across school districts with different incomes, I use data from a paper by David Card and Abigail Payne. ${ }^{65}$ Their paper contains data for all states except for Alaska and Hawaii, and this paper follows suit. ${ }^{66}$ Using the Census of Government and the Census of Population, Card and Payne regress school-districtlevel state 1992 transfers to schools on school-district-level median income. Conducting this regression separately for each state yields a slope coefficient which measures how much each state redistributes across school districts. Using state-level coefficients based on data at the school district level avoids the nearly impossible task of collecting data on school finances for each city. This would be extremely difficult because each state has a different form of local government, and there are often substantial variations within state, including many school districts that are not coincident with cities.

\section{Summary Statistics}

Table 2 presents summary statistics for the key variables, weighted by 1980 population. There are 20,499 observations with complete data at the place level in 1980 and 2010. These observations cover $151,374,780$ individuals, constituting $67 \%$ of the 1980 US population. The mean change in log population, multiplied by 100 , is 17.223 , meaning that the average population-weighted place increased population by roughly 17\% between 1980 and 2010 . The average place’s median household income in 1980 was $\$ 16,960$.

\footnotetext{
${ }^{65}$ See Card \& Payne, supra note 5.

${ }^{66}$ Hawaii has a single, statewide school district. As a result it cannot have redistribution between school districts. John A. Thompson \& Stacey E. Marlow, Hawaii, NATIONAL CENTER FOR EDUCATion STAtistics, http://nces.ed.gov/edfin/pdf/StFinance/Hawaii.pdf (last visited Nov. 2, 2013). Data issues preclude the use of Alaska. See Card \& Payne, supra note 5.
} 
Table 2: Summary Statistics

\begin{tabular}{rrrrr}
\hline Variable & Mean Std. Dev. & Min & Max \\
change in log population (x100), 2010 - 1980 & 17.223 & 41.855 & -494.422 & 430.417 \\
median household income $(\$ 1,000), 1980$ & 16.960 & 5.316 & 0.000 & 75.001 \\
state redistribution: change in state aid per student when school & 3.625 & 2.321 & -1.342 & 16.318 \\
district median household income decreases by \$1,000 & & & & \\
interaction of median household income and redistribution & 61.939 & 44.504 & -36.695 & 657.925 \\
\hline
\end{tabular}

Note: There are 20,499 observations. Statistics are weighted by 1980 population. See text for sources.

The average amount of the state redistribution measure is 3.625. That is, in the average (population-weighted) state, when a school district's median income decreased by $\$ 1,000$, state aid per student increased by $\$ 3.63$ per pupil. States range from highly progressive at 16.318 (Wyoming), to actually regressive, at -1.342 (Louisiana), in which a decrease of $\$ 1,000$ in a district's median income decreases state transfers by $\$ 1.34$ per pupil. I then interact the place median income and state redistribution terms to produce the interaction term, which has a mean of 61.393; how to interpret the coefficient on this number will be explained in the results section.

\section{Results}

Table 3 presents the main results of the paper. I will focus on the main coefficient of interest, $\beta_{1}$ in equation (1), which is the coefficient on the interaction between a place's median income and the amount of redistribution in the place's state. Column (1) contains the results of the regression of population growth on the interaction term; the result is a positive coefficient on the interaction term, suggesting that, the more progressive the state, the more a place's higher median income increases its population growth. This is the opposite of the expectation. Column (2) adds in state fixed effects, addressing "state bias"; that is, these regressions add a variable for each state equal to zero unless the observation is from the appropriate state, thereby controlling for all of the average characteristics of each state. Here, the coefficient increases and stays the same sign. Column (3) adds to column (1) regression the other part of the interaction, 1980 
median income, addressing “poor place bias”; the coefficient shrinks, but stays positive. Column (4) includes both the state fixed effects and median income, and the sign flips, with a coefficient of -0.158 .

Table 3: Effect on Change in Log Population, 1980 to 2010

\begin{tabular}{rcccccc}
\hline & $(1)$ & $(2)$ & $(3)$ & $(4)$ & $(5)$ & $(6)$ \\
interaction of median income and redistribution & $0.123^{* * *}$ & $0.214^{* * *}$ & $0.0726^{* * *}$ & $-0.158^{* *}$ & $-0.142^{* *}$ & $-0.150^{* *}$ \\
& $(0.020)$ & $(0.036)$ & $(0.023)$ & $(0.065)$ & $(0.064)$ & $(0.064)$ \\
median income $(\$ 1,000), 1980$ & & & $0.882^{* * *}$ & $1.830^{* * *}$ & $4.726^{* * *}$ & $8.290^{* * *}$ \\
& & & $(0.166)$ & $(0.273)$ & $(0.399)$ & $(0.892)$ \\
& & & & $-0.0654^{* * *}$ & $-0.205^{* * *}$ \\
median income $(\$ 1,000)$ squared, 1980 & & & & $(0.006)$ & $(0.031)$ \\
& & & & & & $0.00157^{* * *}$ \\
median income (\$1,000) cubed, 1980 & & & & & & $(0.000)$ \\
state fixed effects & & $\mathrm{X}$ & & $\mathrm{X}$ & $\mathrm{X}$ & $\mathrm{X}$ \\
$\mathrm{R}$-squared & 0.017 & 0.242 & 0.027 & 0.253 & 0.264 & 0.266 \\
\hline
\end{tabular}

Note: There are 20,499 observations. Statistics are weighted by 1980 population. See text for sources.

Robust standard errors in parentheses

$* * * \mathrm{p}<0.01,{ }^{* *} \mathrm{p}<0.05,{ }^{*} \mathrm{p}<0.1$

The coefficient's reversal in sign shows the importance of addressing biases by controlling for both cross-state differences and differences in income levels when studying the effect of state transfers to localities on local outcomes. In particular, the results show the importance of comparing states with different levels of redistribution to effectively get a counterfactual of states with little redistribution for states with large amounts of redistribution. For example, merely studying one state would yield results that look, on average, like column (2), which does not control for the place's median income. As the positive coefficient on median income in column (4) shows, a higher median income is positively associated with increased population growth. But it is precisely the fact that higher-income places receive less redistribution from the state through education that I am studying. They key is to separate out these two effects of higher income-the positive effect related to greater economic forces and the negative effect related to school finance redistribution-by controlling for median income 
directly and then comparing places across states which give different levels of school finance redistribution for places with the same median income. ${ }^{67}$

Columns (5) and (6) add terms for median income squared and cubed, respectively. These are potentially important controls in case the effect of median income on population growth is nonlinear. ${ }^{68}$ In these regressions, though, the additional terms have little effect on the coefficient, changing it from -0.158 in (4) to -0.142 in (5) with income squared and -0.150 in (6) with income squared and income cubed.

Since the coefficient in (6) is the most important result in the paper, I will pause a moment to interpret it, especially given that interpreting interaction terms requires extra work. First, the coefficient on the interaction term $(-0.150)$ is highly statistically significant, with a $t$ statistic of 2.36 and a p-value of 0.018 . Second, what the coefficient means is that, on average, poor places grew faster in states with more redistribution, relative to the rest of the places in their respective states. In particular, if two places began with 1980 median income at \$1,000 less than the median income of the average place, the place in the state which redistributed an extra \$1 because of that $\$ 1,000$ lower income grew 0.150 percentage points faster than the place in the state that did not redistribute the extra $\$ 1$. Take the example of Connecticut, a state considered as a case study below. Connecticut, the eighth most redistributive state in the data, redistributed another $\$ 5.95$ per student to cities for each $\$ 1,000$ decline in income. Suppose that it instead redistributed $\$ 0$ and compare the cities of New Haven, with a 1980 median income of $\$ 11,683$ to its neighboring wealthy suburb of Orange, with a median income of $\$ 31,132$. The results

\footnotetext{
${ }^{67}$ In technical economics jargon, when trying to compare redistribution across locations of different income levels while controlling for median income, the regressor of interest and control would be collinear.

${ }^{68}$ To understand why it is important to add higher-order terms, consider the case in which terms $a$ and $b$ are interacted and separately controlled for, and also $a$ has a nonlinear quadratic relationship with outcome variable $y$. Suppose as well that $a$ and $b$ are positively correlated; as a result, the interaction term will partly be picking up the quadratic relationship of $a$ with $y$ and not the effect of the interaction on $y$. Putting in a quadratic term for $a$ directly puts all of the loading of the quadratic relationship on the quadratic term and lets the coefficient on the interaction term express only the effect of the interaction.
} 
suggest that, because of Connecticut's redistribution, New Haven's growth rate was 18.34 percentage points higher between 1980 and 2010 than the growth rate would have been if it had had Orange’s 1980 income. $^{69}$ Given that many poor cities grew very little (only 3.81\% in the case of New Haven) between 1980 and 2010, these results imply that redistribution made a huge difference in achieving relative stability of population relative to rich suburbs in states like Connecticut with large amounts of redistribution across school districts. ${ }^{70}$

The interpretation of the results can be generalized to the whole country. The results mean that the difference in growth between the place in the country at the $10^{\text {th }}$ percentile of income $(\$ 11,951)$ and the place at the $90^{\text {th }}$ percentile $(\$ 24,376)$ in a state with the average amount of redistribution was 7.68 percentage points because of the redistribution. ${ }^{71}$ This difference is nearly half the average place's growth rate of 17.22 percentage points. School finance redistribution appears to be an important part of the "return to the city."

It is also worth noting the large positive effect that median income has on the change in $\log$ population, meaning that population has increased more in wealthier places. ${ }^{72}$ The coefficient on median income is positive and significant in all columns. As well, the relationship appears to be nonlinear, with the negative coefficient on the income squared term, meaning that the effect of having a high income on population growth tapers off somewhat at higher incomes.

\footnotetext{
${ }^{69}$ This calculation is (difference in incomes) * (difference in redistribution) $*$ coefficient $=(11.683-32.232) *(0$ $5.95) *(-0.150)$. Note that Orange had far from the highest median income in Connecticut in 1980. For example, Darien had a median income of $\$ 39,508$, and Westport had a median income of $\$ 40,139$.

${ }^{70}$ Note that, because the coefficient is on an interaction term, it is not possible to say how much more a city like New Haven grew due to the redistribution without making reference to an alternative level of median income. This is why I compare New Haven to Orange.

${ }^{71}$ All these statistics are population-weighted.

${ }^{72}$ This result that wealthy places have grown in population more quickly than poor places is consistent with the findings of Daniel Shoag \& Peter Ganong, Why Has Regional Income Convergence in the U.S. Declined?, (March 2013), available at http://papers.ssrn.com/sol3/papers.cfm?abstract_id=2081216 (showing that between 1990 and 2010, there was no relationship between a state's per capita income and its population growth rate), since they analyze the state level and I analyze the local level.
} 


\section{E. Alternative Explanations}

As noted above, for the results to be valid, it must be the case that the average difference in growth rate between poor and rich places would have been the same within high-redistribution states and low-redistribution states in the absence of school finance redistribution. In this section, I address several potential concerns that could lead to such a difference in growth rates.

First, one potential concern with this analysis might be that states that redistribute more to schools based on income also redistribute more for other reasons. This concern is mitigated substantially by the fact that school funding is the most important source of redistribution directly received by local governments. That said, programs like Medicaid also indirectly redistribute across localities, by paying more for poor residents, which poor locations have disproportionally more of, and local government finances may be affected to some extent by such spending. As well, more redistribution for schools may be correlated with more redistributionary Medicaid programs across states. To the extent that other forms of transfers are correlated across states with more redistributionary school finance schemes, the school finance variable here should be taken as a proxy of state redistributionary behavior, meaning that the impact of a dollar is less than the coefficient suggests, but that redistribution across localities still has a substantial effect along the lines of that suggested by the estimates above. Of course, the opposite could also be true: a state may redistribute more to schools in poor areas and compensate by redistributing less in other ways. But then the measured effects would actually underestimate the true effect of school finance redistribution.

A second potential concern might be that states with poor places that would have done particularly well even without the change in school finance are the states that redistributed more, thus artificially generating the relationship between a large amount of redistribution in a state and 
the strong population growth of poor cities in the state. Figure 2, a map of the amount of redistribution by state in which darker colors indicate more redistribution, alleviates this concern. In particular, although redistribution is certainly correlated with geography, being higher in the northeast and lower in the southeast, there is a great deal of geographic heterogeneity. The state with the greatest amount of redistribution is Wyoming, for example. Texas and Florida also have some of the greatest amounts of school finance redistribution.

Figure 2: Map of State Redistribution

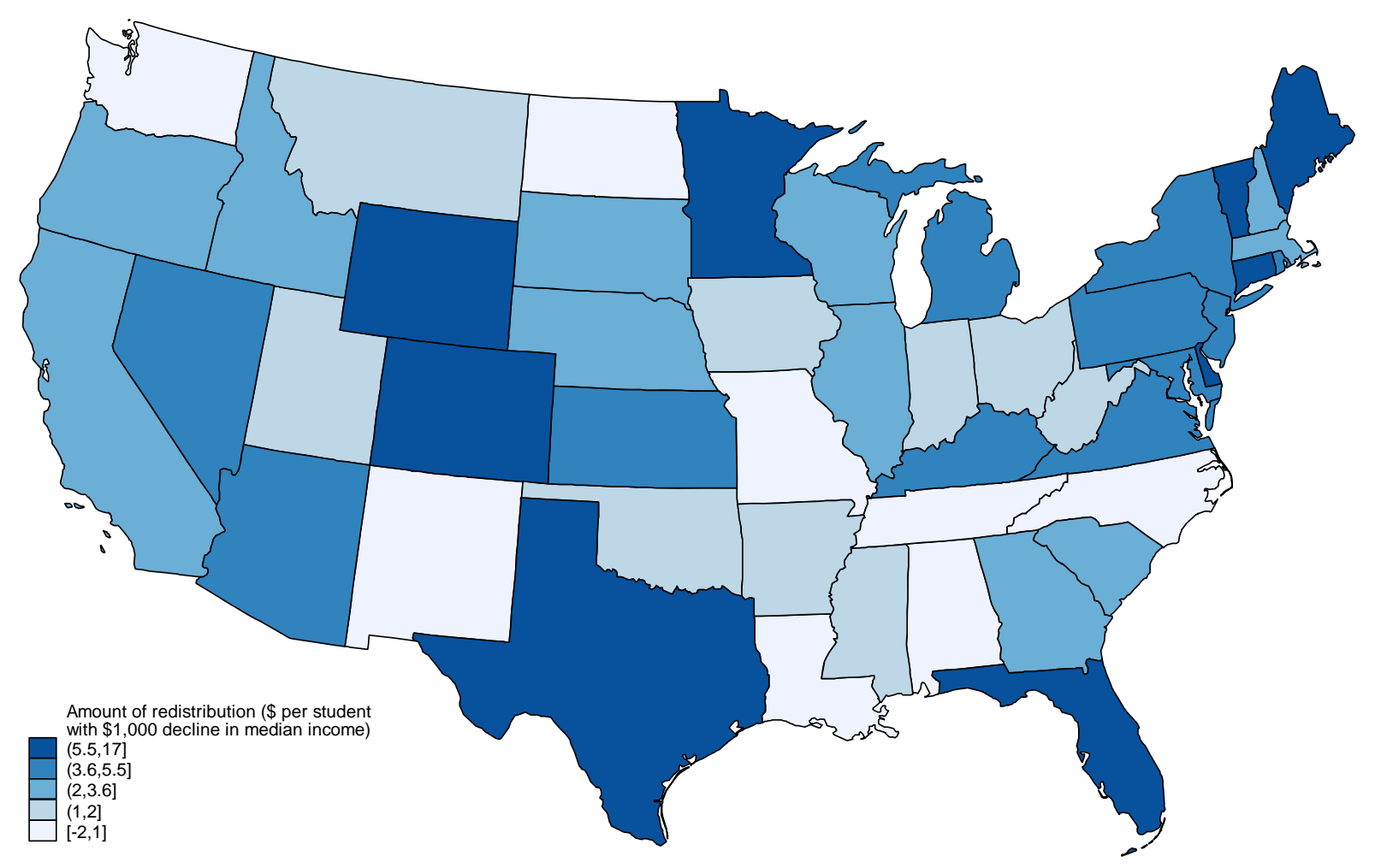

Notes: The redistribution measure refers to 1992.

The apparently significant amount of arbitrariness in the location of high-redistribution states is borne out by the statistics. In particular, if one's concern is that poor places in regions with high amounts of redistribution may have grown more quickly than poor places in regions 
with small amounts of redistribution for economic reasons unrelated to school finance redistribution, the way to address the concern is to measure the effect of having more redistribution within a region. Controls for the effect of income, within region, need to be added in this case. In particular, adding controls for each of the nine Census Divisions ${ }^{73}$ times each of median income, median income squared, and median income cubed (for a total of 27 controls) yields a coefficient on the interaction term which barely changes relative to the main result of -0.150 from column (6) in Table 3. Indeed, the coefficient actually goes up a little in magnitude to -0.185 , with a standard error that stays very similar at 0.075 . Further adding the equivalent 27 controls for population interacted with regional dummies to the 27 income controls similarly barely changes the results, yielding a coefficient of -0.169 , with a standard error of 0.070 . With this evidence, it is apparent that regional differences in the growth rates of poor places for reasons other than school finance redistribution do not drive the results.

Third, one might be concerned that states with a large amount of redistribution also happen to be states with large amounts of annexation activity. Since larger (and therefore, on average, poorer) cities tend to be the cities that grow by annexation, if there were such a relationship, this annexation activity would bias the results, by spuriously generating larger population growth in large cities in states with large amounts of redistribution. To address this concern, I collected all the data on annexations between 1990 and 2010 reported to the U.S.

\footnotetext{
${ }^{73}$ The Census Divisions are as follows: New England Division: Connecticut, Maine, Massachusetts, New Hampshire, Rhode Island, and Vermont; Middle Atlantic Division: New Jersey, New York, and Pennsylvania; East North Central Division: Illinois, Indiana, Michigan, Ohio, and Wisconsin; West North Central Division: Iowa, Kansas, Minnesota, Missouri, Nebraska, North Dakota, and South Dakota; South Atlantic Division: Delaware, District of Columbia, Florida, Georgia, Maryland, North Carolina, South Carolina, Virginia, and West Virginia; East South Central Division: Alabama, Kentucky, Mississippi, and Tennessee; West South Central Division: Arkansas, Louisiana, Oklahoma, and Texas; Mountain Division: Arizona, Colorado, Idaho, Montana, Nevada, New Mexico, Utah, and Wyoming; and Pacific Division: Alaska, California, Hawaii, Oregon, and Washington. 2007 Economic Census: Regions and Divisions, United STATES CENsus, http://www.census.gov/econ/census07/www/geography/regions_and_divisions.html (last visited Oct. 1, 2013).
} 
Census Bureau, comprising 184,041 datapoints. ${ }^{74}$ I then measure the statistical relationship between how much land was annexed during these years (as a fraction of total state land area) and how redistributive the state's school finance system is. The result suggests that there is no relationship ( $p=0.715$ ) and, to the extent that there is one, it goes in the opposite direction so the one that would be concerning for the results above; that is, the more annexation activity, the less redistributive states are.

\section{Understanding the Mechanism: a Case Study on Connecticut}

To better understand the mechanisms driving the effect of financial transfers on population, I drill down on the local finances of Connecticut as a case study. Focusing on one state enables an analysis of the sources, destinations, and ultimate uses of funds, including tax reductions, spending increases in the intended area, and spending increases in other areas. This is essentially impossible on a national scale because local finances differ greatly from state to state.

Connecticut is a good case study for two reasons. First, it had a substantial amount of redistribution, resulting partly from the aftermath of the 1977 Connecticut Supreme court case Horton v. Meskill ${ }^{75}$, which mandated school finance equalization. For example, in the 20122013 proposed Connecticut state budget, New Haven receives $\$ 8,286$ per student and its wealthy suburb of Madison receives $\$ 428$ per student from the state. ${ }^{76}$ Second, its government structure makes it unusually suitable to empirical analysis in that there are essentially only two levels of government in the state, the state and the town. County government does not exist. In almost all

\footnotetext{
74 Boundary and Annexation Survey, UNITED $\quad$ STATES http:/www.census.gov/geo/partnerships/bas/bas_annex.html (last visited Oct. 15, 2013).

75172 Conn. 615 (1977). Unfortunately, data between 1980 and 1989 is not available digitally.

76 Proposed 2012-13 EduCATION COST SHARING ENTITLEMENTS COMPARISONS, http://www.governor.ct.gov/malloy/lib/malloy/ECS_FY2013_Proposed_Increase.pdf (last visited Sept. 10, 2013).
} 
cases, school districts share the same borders as towns. Very few special districts cross town boundaries. This simplicity makes tracking transfers to local governments far more feasible than elsewhere in the country. ${ }^{77}$ Finally, the state government spends almost no money directly on elementary and secondary education, instead transferring nearly all the money to localities; this makes tracking the destination of the funds easier. ${ }^{78}$

\section{A. The Connecticut Story}

Although the state of Connecticut has long transferred state revenue to localities for education, the differential treatment of rich and poor communities resulted from litigation in state courts on unequal access to education. ${ }^{79}$ In Horton v. Meskill, the Connecticut Supreme Court found Connecticut's system of predominantly local financing of schools inconsistent with the state constitution. When the action was brought by plaintiff Horton in 1974, a kindergartner at Canton Elementary School, all school districts received $\$ 215$ per student from the state. ${ }^{80}$ In 1975, as the case was being litigated in lower courts, the legislature increased the grant to \$250 per pupil and added for new funding from lotteries which provided an additional grant of \$12.50 per pupil for poorer towns. ${ }^{81}$ The court found this insufficient. The supreme court noted that state

legislation ... delegates to municipalities of disparate financial capability the state's duty of raising funds for operating public schools within that municipality. That legislation gives no consideration to the financial capability of the

\footnotetext{
${ }_{78}^{77}$ A further reason is that there are virtually no annexations as a confound to population growth.

${ }^{78}$ The state directly spends virtually no money on elementary and secondary education - literally none through 1994, and then very small amounts after that. Instead, the state transfers nearly all of its elementary and secondary education spending to localities. Annual Survey of Governments, supra note 6.

${ }^{79}$ Nicholas Carbone \& Evelyn Brody, PILOTs: Hartford and Connecticut, in ProperTY-TAX EXEMPTION FOR ChARITIES 233, 236 (Evelyn Brody ed., 2002).

${ }^{80}$ Horton v. Meskill, 172 Conn. at 629 (citing ConN. GEN. STAT. § 10-262 (1974)).

${ }^{81}$ Id. at 636-637 (citing ConN. PuB. ACTs 1975, No. 75-344 and Conn. PuB. ACTS 1975, No. 75-341).
} 
municipality to raise funds sufficient to discharge another duty delegated to the municipality by the state, that of educating the children within that municipality. ${ }^{82}$ After reviewing data describing how poorer places have less of a property tax base, less spending, but higher tax rates, ${ }^{83}$ it concluded that the system failed to secure the "fundamental right” to elementary and secondary education under strict scrutiny under the state constitution. ${ }^{84}$ It upheld the trial court's requirement of the "adoption by the state of a financing program designed to achieve a substantial degree of equality of educational opportunity” while still “permit[ting] all towns to exercise a meaningful choice as to educational services to be offered to students.” advantages are not required and cannot be attained except in the most relative sense.»86

After Horton, in 1979, the legislature substantially revised the Guaranteed Tax Base (GTB) established in 1975 to provide more funding for poorer towns. ${ }^{87}$ As well, following the holding in Gallulo v. Waterbury ${ }^{88}$, that municipalities could use state education grants to pay for tax decreases or other services instead of education, the legislature added the minimum

${ }^{82} \mathrm{Id}$. at 648.

${ }^{83} \mathrm{Id}$. at $631-32$.

${ }^{84}$ Id. at 646, 648. The Connecticut Supreme Court rooted its findings in three sections of the Connecticut Constitution. Id. at 638. These three sections in their entirety read as follows: "All men when they form a social compact, are equal in rights; and no man or set of men are entitled to exclusive public emoluments or privileges from the community." СT. CONST. art. I, § 1. "No person shall be denied the equal protection of the law nor be subjected to segregation or discrimination in the exercise or enjoyment of his civil or political rights because of religion, race, color, ancestry or national origin.” Ст. CONST. art. I, § 20. "There shall always be free public elementary and secondary schools in the state. The general assembly shall implement this principle by appropriate legislation.” Ст. CONST. art. VIII, § 20. The trial court had held "that although local control of public schools is a legitimate state objective, since local control of education need not be diminished if the ability of towns to finance education is equalized, the local control objective is not a rational basis for retention of the present financing system; that the state has not selected the less drastic means for effectuating the local control objective and, therefore, the system, beyond a reasonable doubt, violates the constitution of Connecticut.” Horton v. Meskill, 172 Conn. at 638.

${ }^{85}$ Id. at 651-652.

${ }^{86} \mathrm{Id}$. at 652.

87 D'Ann Mazzocca, School Funding and the Courts, OLR RESEARCH RePORT (Aug. 17, 1995), http://search.cga.state.ct.us/dtsearch.asp?cmd=getdoc\&DocId=20445\&Index=I\%3A\%5Czindex\%5C1995\&HitCoun $\mathrm{t}=0$ \&hits $=$ \&hc $=0$ \&req=\&Item $=4000$.

${ }^{88} 175$ Conn. Reports 282 (1978). 
expenditure requirement (MER). ${ }^{89}$ In 1988, the legislature replaced the Guaranteed Tax Base with the Education Cost Sharing (ECS) formula, which has been periodically revised to respond to state fiscal constraints and to "reallocate available state aid to different kinds of towns." Though there have been year-to-year variations, the key point is that, since 1979, the state has redistributed substantially more to towns with lower "wealth," defined in terms of the equalized property tax base as measured by the state of Connecticut. ${ }^{91}$ Broadly ECS aid is calculated in three steps: 1) measure the ratio of town property wealth to the guaranteed wealth level and then subtract this ratio from 1 so that poorer towns receive more money, 2) multiply this ratio by a foundation level of spending, and 3) multiply again by the number of students. ${ }^{92}$

The litigation continued with claims of segregation between schools, which helped result in legislation increasing funding for school construction which was disproportionately used by poor towns. In Sheff v. O’Neill, 238 Conn. 1 (1996), the Connecticut Supreme Court held that the right to substantially equal access to educational opportunity is undermined by extreme racial

\footnotetext{
${ }^{89}$ The case arose from the decision by the board of alderman of Waterbury to lower its property tax to 84.85 mills from a proposed 87 mills, after learning that its share of lottery funds would be about $\$ 1$ million higher than expected; the city allocated the entire expected revenue increase to tax reductions and none to increased education spending. Galullo, 175 Conn at 182, 184. The court made this holding despite the provision in the law which stated, "All aid distributed to a town pursuant to the provisions of [the guaranteed tax base program] shall be expended for school purposes only." Conn. Gen. Stat. § 10-262e. As well, the Court acknowledged that "[t]he remarks made in the senate in support of [this provision] indicate that it was in fact intended to force town to distribute the aid to their boards of education.” Galullo, 175 Conn. at 186. Nevertheless, the Court upheld the trial court in its finding that that the state funds were used for education; implicitly, the local funds which had been proposed for education spending were the ones used for the tax reductions. Id. at 186. The Court added that "[t]he legislative history of the [provision] indicates that legislators were aware of the possibility that tax-burdened cities might see the availability of additional state funds for education as an opportunity to reallocate existing city revenues and reduce taxes.” Id. To find the actions of Waterbury problematic, the law would have needed a "provision . . . which compels cities to use instant lottery funds to supplement the education allotment in their budgets." Id.

${ }^{90}$ Judith S. Lohman, Changes in Education Cost Sharing Formula Since 1988, OLR RESEARCH REPORT (March 26, 1998),

http://search.cga.state.ct.us/dtsearch.asp?cmd=getdoc\&DocId=12398\&Index=I\%3A\%5Czindex\%5C1998\&HitCoun $\mathrm{t}=0$ \&hits $=$ \&hc $=0$ \&req= \&Item $=7835$.

${ }^{91}$ Equalized Net Grand Lists for Purposes of Educational Equalization Grants, ConN. GEN. STAT. § 10-261a.

| ${ }^{92}$ Mazzocca, supra note $\underline{8790 .}$
} 
and ethnic isolation. ${ }^{93}$ The court left the remedy to the legislature. As a consequence, the legislature quickly passed the Enhancing Educational Choices and Opportunities Act. ${ }^{94}$ The legislation included substantial funding for school construction aimed at reducing segregation, allocated mainly in two ways. First, the state would completely fund construction of interdistrict magnet schools if the districts commit to the school for at least twenty years. ${ }^{95}$ Second, schools receive additional funding if their construction projects serve to integrate local schools. If a district builds a new interdistrict magnet school and commits to the new school for at least twenty years, the state provides 100 percent funding for the construction of the building. Additionally, "any school district that builds a school facility that includes extra room for the interdistrict transfer of students will receive funds from the state in an amount that is 10 percent higher than the district's normal reimbursement rate."96 Still, the magnitude of school construction spending is substantially smaller than that for equalization of operating expenses; the state spent a total of $\$ 4$ billion on school construction from 2001 to 2012, ${ }^{97}$ while ECS grants totaled nearly $\$ 20$ billion. $^{98}$

\footnotetext{
${ }^{93}$ For additional analysis on Sheff, see James Ryan, Sheff, Segregation, and School Finance Litigation, 74 N.Y.U. L. REV. 529, 529 (arguing that "school 'finance' litigation need not, and perhaps should not, be solely about money" and that instead "nonmonetary remedies [such] as racial and socioeconomic integration and school choice" should be explored).

${ }^{94}$ Public Acts 1997, No. 97-290.

95 Sheff v. O’Neill, 733 A.2d 925, 929 (Conn. Super. Ct. 1999) (describing the construction subsidies). For additional information on Connecticut's funding of interdistrict magnet schools, see Judith Lohman, State Funding for Interdistrict Magnet Schools, OLR RESEARCH REPORT (March 9, 2010), http://www.cga.ct.gov/2010/rpt/2010-R0056.htm.

${ }^{96}$ Sheff v. O’Neill, 733 A.2d at 933.

${ }^{97}$ Education Finance in Connecticut: Overreliance on the Property Tax, CCM PUBLIC POLICY REPORT 16 (Nov. 2012) http://advocacy.ccm-ct.org/Resources.ashx?id=524d5981-e780-4b8f-bd8d-701de00ca464. Connecticut has consistently not authorized the appropriations up to the level of the permissible statutory limit. Orlando J. Rodriguez \& Jacob Siegel, Problems with Connecticut's Education Cost Sharing Grant, ConNECTICUT VOICES FOR CHILDREN (Feb. 2011) http://www.ctvoices.org/sites/default/files/Bud11CTEduCostSharingGrantProblems.pdf.

${ }^{98}$ This statistic is from my calculations of data from Education Grants Database, CONNECTICUT OfFICE OF POLICY AND MANAGEMENT, http://www.ct.gov/opm/cwp/view.asp?a=3006\&Q=383258\&opmNav_GID=1386 (last visited Sept. 4, 2013).
} 
It is important to emphasize that the school financing system set up in Connecticut is quite different from that in California, the most-studied case of court-ordered school finance reform. In particular, the California Supreme Court required that some portion of high-spending districts' property wealth was "recaptured” for redistribution to low-wealth school districts. ${ }^{99}$ As a result, the initiative Proposition 13 further limited the ability of localities to raise taxes to fund local services. ${ }^{100}$ In Connecticut, in contrast, there is no "recapture" when school districts spend a lot on schools and no limit on their ability to raise taxes for local schools.

A second reason that state transfers to poor cities have increased is Connecticut's pioneering payments in lieu of taxes (PILOT) program, in which the state compensates towns for property tax revenue lost due to property tax exemptions. Before 1978, only state-owned property was part of the state's PILOT program. ${ }^{101}$ Due in part to lobbying by cities and increasing pressure to levy a tax on non-profits to help cities pay for the services they provided to them, Connecticut passed the College and Hospital PILOT program in $1978 .{ }^{102}$ At that point, the state reimbursed localities for $25 \%$ of taxes that state-owned properties would have paid if they had been taxed, and that grew to $45 \%$ two decades later. The amount of reimbursement for colleges and hospitals has increased with time as well, from $25 \%$ when passed, to $40 \%$ in 1987 , $50 \%$ in $1988,60 \%$ in 1991 , and $77 \%$ in $1999 .{ }^{103}$ In fiscal year 2001, total PILOT payments for colleges, hospitals, and state-owned property totaled \$163 million and went disproportionately to poor communities, which tend to be central cities with large amounts of tax-exempt property. ${ }^{104}$ By fiscal years 2011 to 2013, Connecticut was spending about \$200 million per year on PILOT

\footnotetext{
${ }^{99}$ Stark \& Zasloff, supra note $\underline{46} 47$, at 804.

${ }^{100} \mathrm{Id}$.

| ${ }^{101}$ Carbone \& Brody, supra note $\underline{79} 82$, at 241.

${ }^{102}$ Id. at 242-243.

${ }^{103} \mathrm{Id}$.

${ }^{104} \mathrm{Id}$. at 243 .
} 
payments - a substantial amount of money, though approximately one tenth the $\$ 2$ billion per year the state spent on ECS payments. ${ }^{105}$

\section{B. Empirical Analysis}

The primary dataset for studying Connecticut's local finances is the Annual Survey of Governments from the Census Bureau, which has annual data from all Connecticut towns from 1970 to 1999 on revenues and expenditures, including break-downs by type and source. ${ }^{106}$ I will focus on the portion of total revenues (including for school buildings and PILOT) ${ }^{107}$ coming from intergovernmental sources. Note that the time span covered by the Connecticut finance data (1970-1999) differs from that for the national population growth data (1980-2010). This difference is solely driven by data constraints and the desire to use as much data as is available. That said, the time periods also dovetail nicely with the goals for using each dataset. It is desirable to start earlier with the Connecticut data because school finance reform started in the 1970s, so tracing the finances starting then is helpful. Likewise, ending later is desirable for the population data because the responses to changes in school finances are likely to involve substantial lags as argued above.

Figure 3 shows the share of revenue coming from intergovernmental sources from 1970 to 1999 in the top and bottom deciles of Connecticut towns by median income. ${ }^{108}$ It shows that

\footnotetext{
${ }^{105}$ Benjamin Barnes, FY2010-11, FY2011-12 AND FY2012-13 Estimates of State Formula Aid to Municipalities, OfFice OF POLICY AND MANAGEMENT 15, 25 (Sept. 20, 2012) http://www.ct.gov/opm/lib/opm/budget/2012_midterm_budget/pdfs/FINAL_Municipal_Fiscal_Estimates_Book_Se pt_20.pdf.

${ }^{10 \overline{6}}$ Annual Survey of Governments, supra note 6.

107 Federal, State, and Local Governments: Government Finance and Employment Classification Manual: Descriptions of Intergovernmental Revenue Categories, UnITED STATES CENSUS BUREAU, http://www.census.gov/govs/www/class_ch7_ir.html (last visited Sept. 15, 2013).

${ }_{108}$ The median income is from Connecticut Income Data: US Census 2000 Economic Data, ConNECTICUT DEPARTMENT OF ECONOMIC AND COMMUNITY DEVELOPMENT, http://www.ct.gov/ecd/cwp/view.asp?a=1106\&q=250652 (last visited July 15, 2013). Median income from 1970
} 
there has, indeed, been a revolution in Connecticut's local finances. In 1970, the top- and bottom-decile towns received a roughly similar share of their revenue from intergovernmental sources, at $17.8 \%$ and $24.8 \%$ respectively. In the subsequent 29 years, though, the intergovernmental share to the poorest towns approximately doubled to $49.3 \%$, while the intergovernmental share to the richest towns declined by more than half, to $8.5 \%$. In those three decades, the local budgets of Connecticut's poorest towns have been transformed, with nearly half of revenues coming from the state and federal government, while state and federal government transfers have actually declined substantially as a fraction of revenue in the richest cities.

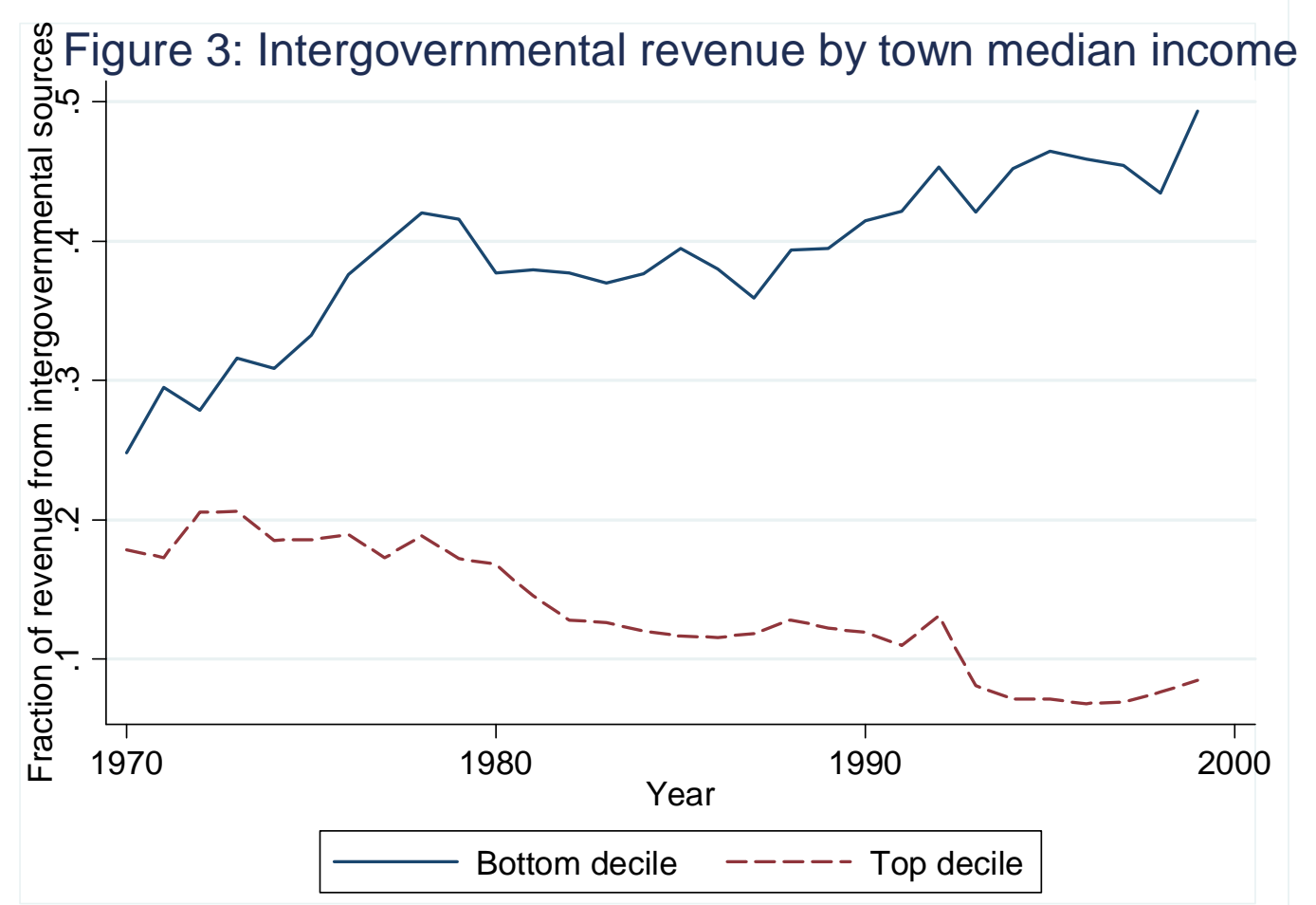

would be more desirable, since it is before any of the changes under study took place, but data from 2000 was more easily accessible, and towns' median income ranking has likely changed little over the past several decades. 
Figure 4 is a scatterplot of the fraction of revenue from intergovernmental sources in 1997, the last year with full data in Figure 3, and median income in 2000. So that the town names are visible, I limit the scatterplot to towns with a population greater than 25,000 . It shows that there is a very strong and generally linear relationship (aside from the hockey-sticky in the bottom right) between median income and intergovernmental revenues. Cities are generally where one might expect them to be; Hartford, Bridgeport, and New Haven - cities with large poor populations - are in the top left corner of low incomes and high intergovernmental transfers, while the rich suburb of Greenwich is in the bottom right corner. Nevertheless, there is a fair amount of dispersion in transfers among cities of roughly similar median income.

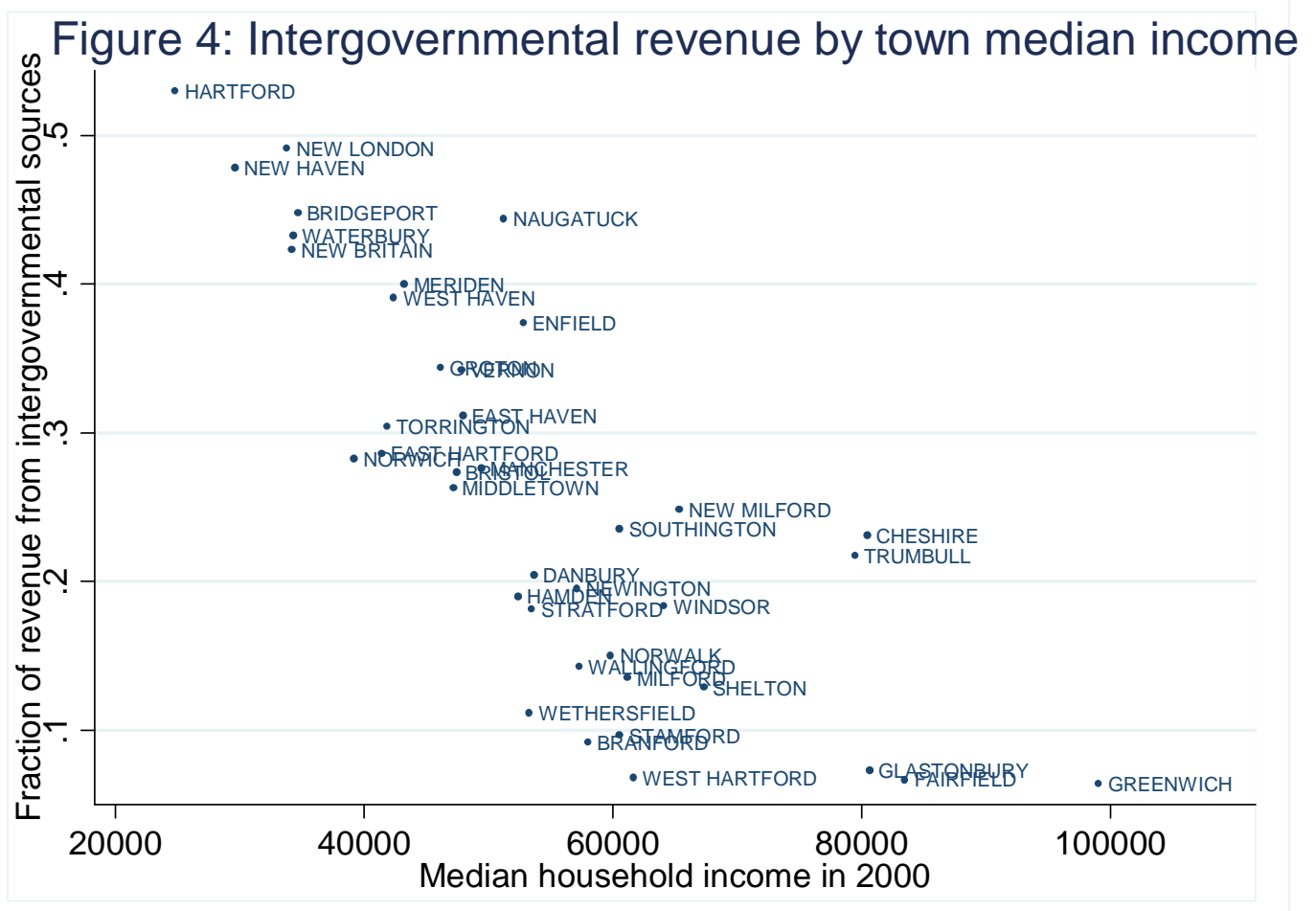


Table 4 shows how intergovernmental revenue in Connecticut is spent, with data from 1997. Connecticut towns received $\$ 2.4$ billion in intergovernmental revenue in 1997, nearly all of which (94.5\%) was from the state government. ${ }^{109}$ Of those intergovernmental transfers from the state, the vast majority was for education; indeed, they constituted $68.7 \%$ of all intergovernmental transfers. This table confirms that, for Connecticut at least, the focus in the first part of the paper on transfers from the state and for schools was appropriate.

Table 4: Connecticut Intergovernmental Revenue in 1997

\begin{tabular}{ccc}
\hline & $\begin{array}{c}\text { Revenue } \\
\text { (\$Millions) }\end{array}$ & $\begin{array}{c}\text { Percent of total } \\
\text { intergovernmental } \\
\text { revenue }\end{array}$ \\
\hline Total intergovernmental revenue & 2,373 & $100.0 \%$ \\
Federal intergovernmental revenue & 110 & $4.6 \%$ \\
State intergovernmental revenue & 2,242 & $94.5 \%$ \\
State education transfers & 1,631 & $68.7 \%$ \\
\hline
\end{tabular}

Note: local intergovernmental revenue forms the remainder.

Source: Census of Governments.

Increased transfers can do several things: increase spending and potentially improve services in the intended area, increase spending and potentially improve services in other areas, and reduce locally-raised taxes. ${ }^{110}$ Table 5 shows for Connecticut how localities have chosen to use their government transfers, using annual data from 1970 to 1999 for all Connecticut towns. ${ }^{111}$

\footnotetext{
${ }^{109}$ An important caveat to this tally is that the federal government provided \$255 million in intergovernmental revenues "for education" and likely other funds that the state then passed onto localities. Unfortunately, the data are not broken down by elementary, secondary, and post-secondary education, so it is not possible to determine how much of this funding was in turn passed to localities for elementary and secondary education. (The data do contain the information that the state government directly spent only $\$ 179,000$ on elementary and secondary education, soto the extent that the federal funding was for elementary and secondary education-it was virtually all passed on to localities.) Thus, the table understates the extent of federal funding as a source of intergovernmental revenue and overstates the role of the state.

${ }^{110}$ For a summary of literature on the extent to which money is spent on its intended purpose (i.e., the "flypaper effect”), see James Hines \& Richard Thaler, Anomalies: The Flypaper Effect, 9 J. ECON. PERSP. 217 (1995).

${ }^{111}$ Some years are not available for some towns.
} 
All the regressions include year and town fixed effects to control for anything that changes across all towns with time and any time-invariant town-level characteristics that may be correlated with how revenue is spent. Also, all regressions are scaled by town population, to make numbers on both sides of the equation per capita. ${ }^{112}$ Finally, all standard errors are clustered at the town level.

Table 5: How Towns Spent the Transfers

\begin{tabular}{|c|c|c|c|c|c|}
\hline & $\begin{array}{c}(1) \\
\text { Per capita } \\
\text { total } \\
\text { revenue }\end{array}$ & $\begin{array}{c}\text { (2) } \\
\text { Per capita } \\
\text { local tax } \\
\text { revenue }\end{array}$ & $\begin{array}{c}(3) \\
\text { Per capita } \\
\text { total } \\
\text { revenue }\end{array}$ & $\begin{array}{c}\text { (4) } \\
\text { Per capita } \\
\text { local tax } \\
\text { revenue }\end{array}$ & $\begin{array}{c}\text { (5) } \\
\text { Per capita } \\
\text { education } \\
\text { spending }\end{array}$ \\
\hline $\begin{array}{r}\text { Per capita intergovernmental } \\
\text { revenue }\end{array}$ & $\begin{array}{c}0.639 * * * \\
(0.096)\end{array}$ & $\begin{array}{c}-0.383^{* * *} \\
(0.070)\end{array}$ & & & \\
\hline $\begin{array}{l}\text { Per capita educational } \\
\text { intergovernmental revenue }\end{array}$ & & & $\begin{array}{c}0.446 * * * \\
(0.157)\end{array}$ & $\begin{array}{c}-0.628 * * * \\
(0.089)\end{array}$ & $\begin{array}{r}0.337 * * * \\
(0.066)\end{array}$ \\
\hline R-squared & 0.913 & 0.891 & 0.901 & 0.900 & 0.886 \\
\hline Town fixed effects & $\mathrm{X}$ & $\mathrm{X}$ & $\mathrm{X}$ & $\mathrm{X}$ & $\mathrm{X}$ \\
\hline Year fixed effects & $\mathrm{X}$ & $\mathrm{X}$ & $\mathrm{X}$ & $\mathrm{X}$ & $\mathrm{X}$ \\
\hline
\end{tabular}

Note: the regressions have 4,311 observations. Standard errors clustered at the town level. *** $\mathrm{p}<0.01,{ }^{* *} \mathrm{p}<0.05, * \mathrm{p}<0.1$

In Table 5, all results are highly statistically significant, at more than the $1 \%$ level. Column (1) shows that, for every $\$ 1$ of intergovernmental revenue, revenue goes up by $\$ 0.64$. Consistent with that, column (2) shows that, for every dollar of intergovernmental revenue, local tax collection goes down by $\$ 0.38$. These two coefficients should add up to 1 , and they roughly do. These results suggest substantial crowdout-that is, money transferred from the state crowded out local funds spent on education. But, of the money that is retained, where is it spent?

\footnotetext{
${ }^{112}$ I measure the data per capita, rather than per student, because — as the regressions show—much of the spending is captured not by the students but by town residents.
} 
The most useful information where money is spent is obtained by dividing the revenue for its "intended" purpose, as labeled in the data, and then seeing where the money ends up. ${ }^{113}$ So, I switch to per capita intergovernmental revenue intended for education to study the effect on education. ${ }^{114}$ The results show that, of an extra dollar of education intergovernmental revenue, total revenue increases by $\$ 0.45$ (column (3)), tax revenue decreases by $\$ 0.63$ (column (4)), and education spending increase by $\$ 0.34$ (column (5)). These results suggest that the majority of education transfers go to reductions in taxes, and, of the remainder, about three quarters goes to education spending, while another quarter goes to other forms of spending.

It is important to emphasize that these results are, at least to some extent, specific to context. For example, law specific to Connecticut likely affects the extent to which towns can use state funds designated for school for something other than the intended purpose. As noted above, in the 1978 case of Gallulo v. Waterbury, the Connecticut Supreme Court held on statutory grounds that towns could divert money intended for schools to other purposes and then added a minimum expenditure requirement. Other states could have different rulings and laws, which would affect the extent of crowdout.

\section{Policy Implications}

\section{A. Discussion}

These results show that increasing transfers to poor places increases spending on services and reduces taxes on their residents, increasing the places' population. Yet, poor places (in

\footnotetext{
${ }^{113}$ Otherwise, the measured effect will mix two factors — first, that less than all of the revenue is intended for any given purpose and, second, that not all money may go to its intended purpose. For example,

${ }_{114}$ The downside is that, if per capita spending for education is correlated with other types of spending, the regressions will be biased.
} 
Connecticut at least) still tend to have the highest property taxes ${ }^{115}$, the worst schools, and the highest crime. ${ }^{116}$ These results and the continued disparity in tax rates suggest that, when a welloff family is considering building a home, it is significantly less likely to choose to live in a poor city merely because new well-off residents must shoulder part of the burden of living in the same municipality as poor families. ${ }^{117}$ The fact that local financing equalization has such a large effect on population growth suggests that much of the unattractiveness of poor cities for new residents may be an artifact of local financing structures, a factor not considered in the Tiebout model. In other words, these results show the importance of local financing structures in reducing development in central cities and increasing sprawl.

This distortion in the location of development due to potential residents facing different tax rates and services in different locations is problematic for two main reasons. The first is that individuals' location decisions deviate from their private optimum because they face different taxes in different jurisdictions. For example, some may want to live nearby work, but will not because of high tax rates. ${ }^{118}$ The problem is particularly stark because the wealthy have highest "cost of time,” making it perhaps most natural for the well-off to live closest to work—even as the well-off may be the ones most discouraged from living in inner cities nearby work. ${ }^{119}$

\footnotetext{
115 The three largest cities, Hartford, New Haven, and Bridgeport, have the highest property taxes. Mill Rates, CONNECTICUT OfFICE OF POLICY AND MANAGEMENT, http://www.ct.gov/opm/cwp/view.asp?Q=385976 (last visited July 28, 2013).

116 The poorest towns tend to have the lowest-rated schools and highest crime rates. Andrew Brady \& Patricia Grandjean, Rating the Towns 2011, ConNeCTICUT MAGAZINE, http://www.connecticutmag.com/ConnecticutMagazine/November-2011/Rating-the-Towns/ (last visited Oct. 9, 2013).

${ }^{117}$ More precisely, these incentives affect potential home-owners, either directly or through builders anticipating the preferences of potential buyers of their homes.

${ }^{118}$ Ellickson, Suburban Growth Controls, supra note 19, at 457 n.212 ("There is widespread agreement among economists that fiscal variations can create allocational problems.”) (citing James M. Buchanan \& Charles J. Goetz, Efficiency Limits of Fiscal Mobility: An Assessment of the Tiebout Model, 1 J. PuB. ECON. 25 (1972) and Michelle J. White, Fiscal Zoning in Fragmented Metropolitan Areas, in FisCal Zoning AND LAND Use ConTrol 31, 31 (Edwin S. Mills \& Wallace E. Oates eds., 1975).

${ }_{119}$ This distortion may be particularly large since household heads with the strongest incentive to live outside jurisdictions with high taxes and poor services are those with school-age children, which is likely correlated with being of prime working age and therefore having a desire to live nearby jobs.
} 
Second, the problems arising from fiscal distortions to location choice are compounded by the potentially large positive externalities associated with living in cities. In other words, the current tax regime promotes land use decisions that are contrary to current policy objectives which aim to promote cities' positive externalities. In particular, with the goal of reducing greenhouse gas (GHG) emissions and improving the quality of life of residents, states around the country have sought to encourage development nearby jobs and transit hubs, precisely where taxes are the highest and local services the worst. ${ }^{120}$ Cities reduce the GHG emissions of their residents first by reducing their vehicle miles travelled in cars because of the availability of transit and proximity to jobs. ${ }^{121}$ They also reduce residents’ GHG emissions because the higherdensity development likely to occur in cities also uses less energy by virtue of being in multi-unit dwellings, which consume less energy than single-family dwellings per square foot because units are surrounded by other units rather than the outside. ${ }^{122}$ In addition to the environmental concerns, many argue that cities induce agglomeration economies resulting from spillovers in ideas and greater labor market depth. ${ }^{123}$ Finally, there may be sociological benefits of promoting a return to the city by the middle class. ${ }^{124}$ As argued by William Julius Wilson, middle-class individuals attracted to cities may be particularly valuable as role models to youths. ${ }^{125}$ Similarly, as long as there are not offsetting losses elsewhere, the political benefits that Richard Briffault

\footnotetext{
${ }^{120}$ See, e.g., Mark Zaretsky, Malloy Announces New Panel to Address Transit Development in Connecticut, NEW HAVEN REGISTER (Dec. 10, 2012).

http://www.nhregister.com/articles/2012/12/10/news/doc50c65cb67291d290294827.txt?viewmode=fullstory (describing Connecticut Governor Daniel Malloy’s attempt to increase transit-oriented development).

${ }^{121}$ Reductions in vehicle miles travelled also reduces congestion and the need to build more highways, which is important as the funds available for highway construction decline.

${ }^{122}$ See, e.g., Edward Glaeser \& Matthew Kahn, The Greenness of Cities: Carbon Dioxide Emissions and Urban Development, 67 J. URB. ECON. 404 (2010) (arguing that residents in cites emit fewer greenhouse gases per capita).

${ }^{123}$ See Schleicher, supra note 28.

${ }^{124}$ There is at least anecdotal evidence that the middle class is returning to cities. See AlAn EHRENHALt, ThE GREAT INVERSION AND THE FUTURE OF THE AMERICAN CITY (2013).

| ${ }^{125}$ WILSON, supra note 4344.
} 
describes—of able citizens moving back to cities and improving political accountability—are also potentially valuable reasons to promote the return of the middle class to cities. ${ }^{126}$

Even with growing redistribution, it remains the case that high taxes and poor services are bundled into living in cities, since cities have large numbers of poor people. This is problematic for two reasons-first, the private distortion and, second, the social harm from encouraging individuals to live high-negative-externality lifestyles. In other words, the current tax regime for funding local governments has substantially hindered not only private choice but also social development goals.

\section{B. Implications for the Value of Place-Based Policies}

More broadly, this work also informs the debate on the value of place-based policies, which "target transfers toward particular geographic areas rather than groups of individuals."127 First, this research emphasizes what school finance redistribution really is—one of the largest, if not the largest, program of place-based subsidies in the country. ${ }^{128}$ Consider whether school finance redistribution is better considered as benefitting a "geographic area" (poor cities) or a "group of individuals" (poor students). In particular, consider a poor individual deciding between living in a rich place and a poor place in a state which has just implemented school finance redistribution. The poor city will likely have better schools and lower taxes as a result of

\footnotetext{
${ }_{127}^{126}$ Briffault, supra note 24, at 805-806.

${ }^{127}$ Matias Busso, Jesse Gregory \& Patrick Kline, Assessing the Incidence and Efficiency of a Prominent Place Based Policy, 103 Am. Econ. Rev. 897, 899 (2013). See also Timothy J. BArTiK, Who Benefits From State AND LOCAL ECONOMIC DEVELOPMENT POLICIES? (1991) (providing a comprehensive taxonomy of place-based policies). ${ }^{128}$ The Government Accountability Office estimates that the federal government spends about $\$ 15$ billion annually on economic development grants to communities with high rates of poverty and unemployment. Federal Economic Development Grants to Communities with High Rates of Poverty and Unemployment, GovernMENT AcCOUNTABILITY OfFICE, GAO-12-938R (2012). A recent New York Times article estimated that the states and local government spend $\$ 80$ billion annually for similar purposes. Louise Story, As Companies Seek Tax Deals, Governments Pay High Price, N.Y. Times, Dec. 1, 2013, at A1. State governments spent a much larger \$347 billion on schools in 2000. Annual Survey of Governments, supra note 6.
} 
the school finance redistribution, so it is more attractive for the poor person. However, the same is true for a rich person! The poor place will, of course, have a disproportionately large number of poor people, so poor people will disproportionately benefit from the policy-but this is precisely what place-based policies do. A “person-based” policy could provide a voucher to a poor person to attend a private school or just provide a transfer to the individual; the benefits from these policies would not be largely captured by the place, rather than the person. To my knowledge, school finance redistribution has not previously been framed as a place-based policy. The lens of place-based policy-making is important for assessing the value of school finance redistribution - and vice versa: the experience with school finance redistribution is helpful for assessing the value of place-based policies. The "standard" economics view is to be skeptical of such subsidies, as subsidizing precisely the places that are least productive. ${ }^{129}$ Indeed, under the traditional skeptical view, place-based policies merely move people from one place to another without increasing welfare.

However, recent research has called this traditional skepticism into question. ${ }^{130}$ In particular, the traditional models depend on an idea of "spatial equilibrium," which implies that

129 LOUIS WinNICK, Place Prosperity Vs. People Prosperity: Welfare Considerations in the Geographic Redistribution of Economic Activity, in ESSAYS IN URBAN LAND ECONOMICS 273 (1966) (arguing that place-based policies merely redistribute the location of employment and housing, rather than increasing welfare in aggregate). See also Edward L. Glaeser \& Joshua D. Gottlieb, The Economics of Place-Making Policies, 2008 BROOKINGS PAPERS ON ECON. ACTIVITY 155, 227 (2008) (“[P]olicies that aid poor places are not necessarily redistributive and will have indirect consequences, for example pushing up housing costs and inducing poor people to move to poor areas.”)

| ${ }^{130}$ Busso, Gregory \& Kline, supra note 127130 , at 914 ("If most agents are inframarginal in their commuting and residential decisions, deadweight loss will be small and local workers will reap the benefits of place based interventions. If, on the other hand, agents have nearly identical preferences . . . deadweight loss will be substantial and government expenditures will be capitalized into land rents.”) See also the earlier critique JEROME Rothenberg, George C. Galster, Richard V. Butler \& John R. Pitkin, The Maze of Urban Housing MARKets: TheOry, Evidence, AND Policy (1991) (emphasizing the importance of inertia and housing submarkets). Gyourko, supra note 2, also advocates for place-based policies. 
each individual is indifferent between where he lives and every other place. ${ }^{131}$ Importantly, these models do not take into account that individuals differ from each other. In particular, individuals are not indifferent between living in one place and all other because of idiosyncratic preferences, moving costs, social networks, location-specific skills, and a variety of other factors. The seemingly obvious point that everyone is not indifferent between their current location and every other location has big implications for place-based policies: individuals can benefit from such policies, which may be a desirable way to target needy individuals. This paper qualifies this strand of recent theory: there actually has been a large movement in population in response to school finance redistribution, meaning that many of the individuals benefitting from the redistribution may not be the intended beneficiaries.

But recent economics research has also emphasized a second reason to be more sympathetic to place-based policies: even if much of what place-based policies accomplish is moving people from one place to another, that could be advantageous, if certain agglomeration economies are at play. ${ }^{132}$ For example, if place-based policies move people to cities, and those additional people make existing residents more productive without having an offsetting effect on the places that those people would otherwise live, place-based policies can improve overall welfare just by moving people from one place to another. So, if agglomeration externalities are significant in cities, then the place-based policies that bring more people to cities should seem

\footnotetext{
${ }^{131}$ The classic statements of spatial equilibrium are Jennifer Roback, Wages, Rents, and the Quality of Life, $90 \mathrm{~J}$. Pol. ECON. 1257 (1982) and Sherwin Rosen, Hedonic Prices and Implicit Markets: Product Differentiation in Pure Competition, 8290 J. POL. ECON. 34 (1974).

${ }^{132}$ Patrick Kline, Place Based Policies, Heterogeneity, and Agglomeration, 100 AM. ECON. Rev. 383 (2010) ("My conclusions are shown to depend critically upon the degree of preference heterogeneity in the population and the structure of any agglomeration economies.”). See also Patrick Kline \& Enrico Moretti, Local Economic Development, Agglomeration Economies, and the Big Push: 100 Years of Evidence from the Tennessee Valley Authority, Q.J. Econ. _ (forthcoming) (measuring the agglomeration economies resulting from the Tennessee Valley Authority and showing that, while there were agglomeration economies, they were offset by losses elsewhere).
} 
more valuable because of the results in this paper showing that more people move to cities in response to the policies.

This paper also introduces two new reasons to embrace place-based policies that benefit cities. First, the class of positive externalities extends beyond agglomeration economies to environmental and sociological externalities, as described above. Second, place-based policies benefitting cities counteract other "place-based" policies resulting from the structure of local finances that discourage city living. Again, even if place-based policies only induce people to move, that can be a good thing. In other words, the traditional critique of place-based policiesthat they change people's locations without improving welfare-no longer holds when there are existing policies discouraging people from living in cities. ${ }^{133}$ In fact, the traditional critique of place-based policies is flipped on its head: instead of place-based policies being ineffective because that they merely redistribute population, place-based policies are effective to the extent that they do redistribute population to where it is most efficient for them to live.

\section{Policy Implications}

This paper documents how large an effect the uneven local finance playing field has in residential locations choices, distorting behavior significantly. This distortion is problematic on its own and also because distorting people away from cities increases their negative externalities on others. The results then lend fodder to several policy proposals. For example, consolidating metropolitan tax bases or even consolidating localities into metropolitan area governments would address the problem identified here. ${ }^{134}$ But consolidating governments would also affect

\footnotetext{
133 This is a version of the "theory of the second best," stating that once there is already a distortion, a second "distortion" can actually be welfare-improving. See Richard G. Lipsey \& Kelvin Lancaster, The General Theory of Second Best, 24 REV. ECON. STUD. 11 (1956).

| ${ }^{134}$ See Downs, supra note 3738 , and ORFIELD, supra note 3738.
} 
decision-making on issues like land use that are beyond the scope of this paper. While the evidence here should push policy-makers toward metropolitan consolidation, recommending such a policy would depend on determinations of other factors not studied here.

Rather, the most direct policy implication of this paper is strengthening the case to equalize local financing on efficiency grounds. ${ }^{135}$ In particular, states ought to increase funding for poor localities. In the context of Connecticut specifically, the results here bolster the policy of education reformers arguing for the state to "fully fund” its ECS grants. ${ }^{136}$ Year after year, the Connecticut legislature has failed to authorize the maximum statutory amount of grants to poor school districts. And Connecticut redistributes a relatively large amount, suggesting that other states have even more scope to increase their grants to poor school districts.

There are limits, though, to the extent states may engage in such equalization without harming their competitive advantage relative to other states. The more Connecticut raises its income tax on the rich to fund redistribution to low-income towns, the more the rich are likely to leave Connecticut. ${ }^{137}$ The limitations on states' abilities to redistribute and the continuing locational distortions suggest that federal involvement may be useful. Indeed, the argument that redistribution is a national public good has been used throughout Supreme Court jurisprudence. $^{138}$

\footnotetext{
${ }^{135}$ Many proposals existing for remedying inequalities in school financing. Laurie Reynolds develops a proposal for a statewide property tax. Laurie Reynolds, Uniformity of Taxation and the Preservation of Local Control in School Finance Reform, 40 U.C. DAVIS L. REV. 1835 (2006).

| ${ }^{136}$ See Rodriguez \& Siegel, supra note $\underline{97100}$, and Education Finance in Connecticut, supra note 97100.

${ }^{137}$ The geographic mobility of the rich in response to income taxes has little credible evidence. One recent study, though, shows that the country of residency of European soccer players is quite responsive to tax rates. Henrik Kleven, Camille Landais \& Emmanuel Saez, Taxation and International Mobility of Superstars: Evidence from the European Football Market, 103 AM. Econ. REV. 1892 (2013).

${ }^{138}$ See, e.g., United States v. Darby, 312 U.S. 100, 108 (1941) (upholding under the Commerce Clause labor market regulations which sought to redistribute to the poor via better workplace conditions because "interstate commerce should not be made the instrument of competition in the distribution of goods produced under substandard labor conditions, which competition is injurious ... to the states from and to which the commerce flows" through a race to the bottom in labor practices).
} 
As a result, these results suggest that the federal government should redistribute more to poor cities to improve locational efficiency. In 2012, the federal government paid \$14.5 billion $^{139}$ in aid to local education agencies for students at schools with large numbers of poor students ${ }^{140}$, as provided for in Title I of the Elementary and Secondary Education Act of $1965^{141}$ and amended by the No Child Left Behind (NCLB) Act of 2001 ${ }^{142}$. NCLB authorized increasing appropriations, up to $\$ 25$ billion in 2007. ${ }^{143}$ However, these funds have not been authorized by Congress. To put even this number in context, if the federal government redistributed as much per capita as Connecticut did in 2012, it would redistribute $\$ 165$ billion in school financing. A first act to improve allocational efficiency would be for Congress to follow through on its earlier allowances and fully fund NCLB - and then expand the allocation.

Broadly, I advocate a shift in the nature of taxes which fund local services—with a decrease in the use of the local taxes and greater use of state and federal taxes to fund local services. With these increases in federal and state funds to local school districts, legislators would achieve not only the greater equality long sought by education reformers, but also improve efficiency in where people live. Efficiency improves because leveling the local finance playing field gives people the opportunity to live in their desired locations without facing a higher tax burden and worse services in jurisdictions with a large number of poor people. But efficiency also improves because evidence is accumulating that city living is socially beneficial. Increasing redistribution at the federal level would promote these goals not only by further

\footnotetext{
${ }^{139}$ Fiscal Year 2014 Appendix: Budget of the U.S. Government, OffiCE OF MANAGEMENT AND BudgEt 321, http://www.whitehouse.gov/sites/default/files/omb/budget/fy2014/assets/appendix.pdf (last visited Sept. 20, 2013).

${ }^{140}$ Some of this money is passed through states, but it ultimately reaches local school districts.

14120 U.S.C. § 6301 (2013).

${ }_{142}^{142}$ No Child Left Behind (NCLB) Act of 2001, Pub. L. No. 107-110.

14320 U.S.C. § 6302 (2013).
} 
leveling the playing field within states, but also by reducing the ability of the wealthy to avoid the taxes needed to fund this redistribution by moving across state borders.

Of course, to expand aid to poor cities, many details would have to be worked out, and various pitfalls avoided - though detailed discussion of these issues is beyond the scope of this paper. For example, if the aid is nominally "for schools," policy-makers would need to decide if the aid would be per capita or per pupil—and, if the latter, how to deal with charter schools. Federal and state authorities should also be alert to the concern of wasted money ${ }^{144}$, perhaps by using audits and minimizing the extent to which worsening a city's fiscal situation increases aid (e.g., by conditioning payments on poverty rather than budget deficits). Ultimately, while no policy will be without concerns, this paper improves the argument for place-based aid to poor cities.

\section{Conclusion}

The evidence in this paper suggests that state transfers have played a substantial role in maintaining the populations of poor cities, driving the "return to the city." These population shifts are driven by a virtual revolution in local finances, in which poor cities have become increasingly funded by the state. In the case of Connecticut, these transfers have yielded both the intended increases in school spending and also unintended reductions in tax rates in poor cities. The fact that people are so responsive to transfers from the state suggests that the problems that poor cities face may be largely an artifact of local financing and that, if new residents faced similar tax rates and services in cities and suburbs, cities would grow even more. In other words, while arguments in favor of helping cities on the basis of social equity are commonplace, this paper has emphasized an efficiency argument for transfers to localities - removing the distortion

\footnotetext{
${ }^{144}$ For example, officials in Detroit stole money. Mary M. Chapman, Former Mayor of Detroit Guilty in Corruption Case, N.Y. TIMES, Mar. 11, 2013, at A12.
} 
to location choice arising from the poor services and high tax rates that come from the concentration of the poor in cities. The results suggest that it may be worth considering other place-based policies to continue removing this distortion to location choice. 